\title{
The Supreme Court of India: A People's Court?
}

\author{
Introduction
}

The Supreme Court of India has long been thought of as a court for the common people. This perception is rooted in the Indian constitution, which grants the Supreme Court original jurisdiction to hear cases alleging violation of fundamental rights. ${ }^{1}$ The Court has also embraced this vision of its role, and conceives of itself as an institution of "last resort for the oppressed and bewildered." In a judgment from 1987, it expressly notes that it gives greater access to certain marginalized groups:

this Court has always regarded the poor and the disadvantaged as entitled to preferential consideration than the rich and the affluent, the businessmen and the industrialists. The reason is that the weaker sections of Indian humanity have been deprived of justice for long, long years: they have had no access to justice on account of their poverty, ignorance and illiteracy. . . . The majority of the people of our country are subjected to this denial of access to justice and, overtaken by despair and helplessness, they continue to remain victims of an exploitative society where economic power is concentrated in the hands of a few and it is used for perpetuation of domination over large masses of human beings. This court has always, therefore, regarded it as its duty to come to the rescue of these deprived and vulnerable sections of Indian humanity in order to help them realise their economic and social entitlements and to bring to an end their oppression and exploitation. ${ }^{3}$

The Court's self-conscious pro-poor discursion is most evident in its public interest jurisprudence, through which the Court removed many procedural barriers to accessing the Court; and assumed wide ranging remedial powers to ameliorate a range of socio-economic injustices.

Critics of the Court however argue that at least since the 1990s the Court has turned away from this orientation towards the interests

${ }^{1}$ Article 32, Constitution of India.

2 Upendra Baxi, Taking Suffering Seriously: Social Action Litigation in the Supreme Court of India, 4(1) Third World Legal Studies 107 (1985).

${ }^{3}$ Bihar Legal Support Society v. Chief Justice of India, AIR 1987 SC 38. 
of marginalized groups. ${ }^{4}$ Instead, in a time of increasing economic liberalization, the Court has adopted the neo-liberal ideology of the state and has moved towards a more business-friendly jurisprudence, at the cost of marginalized groups, which no longer "have the Court on their side." Upendra Baxi has called this shift the "Structural Adjustment of Judicial Activism" to mirror the structural adjustment of the Indian economy post-1990. Prashant Bhushan, a prominent public interest lawyer in the Supreme Court laments the Court's "venerat[ion] the virtues of the free market and undermin[ing of] the role of the state in providing education, jobs, and the basic amenities of life to its citizens."6

Varun Gauri has sought to empirically demonstrate this shift in the Court's priorities by examining the win rates of different groups in public interest litigations. He finds that:

Win Rates for fundamental rights claims are now significantly higher when the claimant is from an advantaged social group than when he or she is from a marginalized group. That constitutes a social reversal both from the original objective of public interest litigation and from the relative win rates in the 1980s.

While Gauri's analysis is limited to Public Interest Litigation, his methodology of examining win rates to determine which groups are "favoured" by the Court, appears intuitively appealing. Similarly, Shylashri Shankar in examining the Supreme Court's disposition towards anti-terror laws and social rights, concludes that the Supreme Court disfavors certain litigants when she observes that their win rates decrease over time. ${ }^{7}$

In this paper, we examine this assumption regarding the Court's priorities through an empirical analysis of every case published by the

\footnotetext{
${ }^{4}$ See e.g., Mayur Suresh and Siddharth Narrain, The Shifting Scales of Justice: The Supreme Court in Neo-liberal India, Orient BlackSwan (2014); Prashant Bhushan, Supreme Court and PIL: Changing Perspectives under Liberalization, Economic and Political Weekly, 39 (18): 1770-74.

${ }^{5}$ Usha Ramanathan, In the Name of the People: The Expansion of Judicial Power, in, Mayur Suresh and Siddharth Narrain, The Shifting Scales of Justice: The Supreme Court in Neo-liberal India, Orient BlackSwan (2014).

${ }^{6}$ Prashant Bhushan, Supreme Court and PIL: Changing Perspectives under Liberalization, Economic and Political Weekly, 39 (18): 1770-74.

7 Shylashri Shankar, Scaling Justice, India's Supreme Court, Anti-Terror Laws, and Social Rights, Oxford University Press (2009).
} 
Supreme Court from 2010 to 2014. Focusing on the Court's discretionary appellate jurisdiction (technically the Special Leave Petition or "SLP" jurisdiction), we examine what types of cases the Court prioritizes for appellate review. In turn, this analysis helps us determine whether the Court has distinct social priorities in terms of which social groups it favours for access. We compare win rates across different categories of litigants to determine whether some types of cases or litigants have greater access to the Court. We note that our focus is on how to interpret differences in win rates across cases; we do not to examine changes in win rates over time.

Contrary to common perception, we conclude that, at least with respect to the broad categories we can measure, the Court does favor for access less powerful actors over comparatively more powerful ones. Specifically, we find that the Court favors individuals over the government in civil cases, defendants over the prosecution in criminal cases, and cases involving constitutional challenges over other cases. In the first and second instance, the Court is favouring for access the 'less powerful' or more disadvantaged party. Of course, there may be exceptions to the norm of the general power equation between parties. But exceptions aside, we find that in at least these three senses (i.e., individuals, criminal defendants, and constitutional claimants) the Court is still a 'people's court'.

Although we also examine win rates for different types of litigants and cases, we draw a different conclusion than the other authors mentioned above. Gauri, for example, assumes that more wins implies a favorable bias from the Court, but this misses a crucial step in the workings of the Court. Under its discretionary jurisdiction, the Supreme Court is not required to hear every case that seeks admission. It selects which cases to admit. The judges who make the admissions decision also impose their own set of values on the case. Taking this stage into account, and borrowing from the logic of the "hit-rate analysis" used in empirical studies of racial profiling, we, unlike Gauri, argue that lower win rates of one category of litigant as compared to win rates of another category of litigants actually suggests that the Court is giving preferential treatment at the admissions stage to the category of litigants with the lower win rates, by admitting relatively weaker cases for a merits review from the preferred category. This in turn translates into lower win rates for such categories.

On the other hand, for courts that are required to admit every case that is filed (subject to meeting the filing requirements), Gauri and other author's conclusions are more likely to be accurate. In those courts, (1) higher win rates for one category over another category of litigant during the same time period, or (2) higher win rates of one 
category of litigant at a certain period of time as compared to the win rate of that group at another period of time, may suggest that that court is favoring at the merits stage the category of litigant that has the higher win rate. However, in the case of courts that are able to accept some cases and reject some cases this inference is less plausible.

If there is bias in favor of certain groups, we believe that it is more likely to manifest itself at the admissions stage rather than the merits stage. It seems less controversial to prioritize certain groups for admissions based on their characteristics than to rule in their favor of them at the merits stage just based on those characteristics. Thus, we conclude that when a win rate is lower for one category of litigants than another category of litigants, what the Court is doing is taking weaker cases from the former category (in other words, the Court favors that category for access). In this context, by "favors for access," we mean that the Court is more likely to admit and give a full hearing to a petition brought by a member of a relatively disadvantaged group (e.g., a criminal defendant) than to a petition from a member of a powerful group (e.g., the central government), all else being equal.

For example, criminal defendants may petition the Court to review their convictions, and the government prosecutors may petition the Court to review judgments refusing to convict. The Court seeks to correct lower-court error, so it tends to admit petitions that present a strong case for reversal. Thus, when the Court believes that, after a full hearing, it will reverse the lower court, it will admit the petition. For petitions brought by prosecutors, if the Court does not foresee a strong chance of reversing, the Court will deny the petition. But we would hypothesize that a court which prioritizes greater access for criminal defendants would be willing to admit petitions from some defendants, even when chances of reversing their convictions are low. If so, then on average, the merits judgments in petitions brought by prosecutors will tend to reverse the lower court, while on average, merits judgments in petitions brought by criminal defendants will have a weaker tendency to reverse, because the Court is more willing to accept weak petitions from defendants at the admissions stage.

Our interpretation of win rates borrows from the logic of the "hitrate analysis" used in empirical studies of racial profiling. Our analysis rests on a key assumption about how the Court is choosing cases. Common law courts perform at least two functions through their adjudicatory practices. First, they resolve individual disputes about the rights and obligations of disputing parties and provide remedies for violations thereof. Second, through individualized dispute resolution, courts also articulate the general legal norms applicable to that class 
of cases. Importantly, most disputes that arise do not implicate new or undeveloped legal norms; not every dispute will require a court to articulate a new norm. Most disputes will only require a court to apply a clear norm to the facts of the case.

Litigants may request an apex court to review a decision of the lower court for reaching an erroneous result, without calling upon the court to announce new law or resolve splits in lower-court authority. Of course, litigants may also request an apex court to review a decision of the lower court for purposes of announcing new law or resolving splits in lower-court authority. We refer to this as "norm elaboration" in contrast to individualized error correction. The U.S. Supreme Court is a prime example of a court focused on norm elaboration. Rarely does that court reverse cases solely on the basis of an error of fact or misapplication of law to fact though it sometimes does so. ${ }^{8}$

We believe that most petitions for review submitted to the Supreme Court of India have the character of requesting individualized error correction, and the Court decides whether to admit or deny the petition based on a judgment about the likelihood it will reverse the lower court decision after finding error. To be sure, as we describe in more detail in Part II, certain segments of its docket (writ petitions and public interest litigations) may be primarily devoted to norm elaboration. But we focus on the largest part of the Court's docket (special leave petitions, which make up the vast majority of the Court's docket), and as we argue in Part III, the Court's treatment of the run of the mill special leave petitions fits the "individualized error correction" model well: animated by a (sometimes explicit) desire to address every injustice between the parties, the Indian Supreme Court reviews cases for potential error even when no significant legal question (or any legal question at all) is contested. In this paper, we call this approach "case-by-case rescue" to highlight the Court's focus on preventing or remedying injustice between parties in individual disputes. "Rescue" also highlights the Court's aim of providing succor and justice for individuals who come before it. Of course, as a byproduct of the process of case-by-case rescue, the Court may end up (implicitly or explicitly) articulating or signaling new norms. Our contention merely is that the Court's focus in selecting cases for admission under its SLP jurisdiction is not primarily based on the consideration of 'norm elaboration.'

8 Our comparison to the functioning of the U.S. Supreme Court is not meant to suggest that court is a model that the Indian Supreme Court should follow, but merely to offer a contrasting example. 
Because we find that the Court favors for access individuals versus the government, "case-by-case rescue" is not only something different from "norm elaboration," it is notably different from "error correction." The Court is diverting its attention away from the goal of correcting as many errors as possible (which would be accomplished by admitting the strongest petitions, regardless of the identity of the petitioner) and toward to the goal of providing a "day in court" to larger numbers of individual litigants, even those with weaker arguments.

Further, the Court's vision of case-by-case rescue is a SupremeCourt-centric one: by definition, the petitioners whom we study have come to the Supreme Court after having had their "day in court" already, in a lower court-and sometimes in two or three different lower courts. But this seems not to matter much to the Supreme Court. In particular, we find that the Court is no less willing to admit a petition when multiple lower courts have heard petitioner's case and they have all decided the case the same way, even though (as we find) agreement among the lower courts on the outcome of the case is a predictor of the Supreme Court ultimately affirming their judgment. This suggests that the Court envisions itself as the forum where justice can be more accurately delivered for people as compared to lower courts.

This analysis focuses solely on the Court's role as an appellate court. The Indian Supreme Court, of course, has important roles as a court of original jurisdiction, perhaps most notably in entertaining public interest litigations ("PILs"). In this paper, however, our focus is on the Court's role as the apex appellate court of the Indian judiciary, and how it exercises its appellate function. We recognize that given the Court's bench structure and decentralized decision making, it is often difficult to talk about the Court as a single institution. However, while there are important questions to explore regarding differences between individual justices or benches in their approach to admitting or deciding cases, our focus in this paper is on the aggregate operation of the Court, and the access that it provides to persons approaching it.

Our quantitative analysis is informed by dozens of conversations and consultations with current and former justices of the Supreme Court, judges of Indian high courts, senior advocates, court administrators, and academics. Statistical analysis will obviously not capture many facets of questions we examine. More data on other aspects of the Supreme Court will help-and we are currently reviewing data on millions of petitions for review filed with the Court-but ultimately, any prescriptions for the Court must depend on quantitative evidence, qualitative evidence, and a careful assessment of the normative criteria by which the evidence is assessed. For example, our data says nothing about the direction of the Court's substantive jurisprudence, 
which might indeed disfavour the common person. Our analysis is limited to examining the categories of litigants that are favoured for $a c$ cess to the Court under its SLP jurisdiction.

This project is especially timely because it informs many active debates in India. Over the last several years there have been many calls to reform the Indian Supreme Court. The media, prominent lawyers, non-government organizations, justices, ${ }^{9}$ and academics have identified a host of problems with the Court's functioning, including long delays for case resolution. Suggested solutions to the problem include creating regional benches of the Indian Supreme Court, a separate constitutional court, and a new appeals court between the Court and High Courts. ${ }^{10}$ Indeed, Justice Thakur, a recently retired Chief Justice of India, last year ordered the Indian Supreme Court to weigh in on this conversation. ${ }^{11} \mathrm{He}$ admitted a public interest litigation case asking that a new court of appeals be created between the High Courts and the Indian Supreme Court. The matter has been referred to a constitutional bench to identify areas of reform and to propose potential solutions. ${ }^{12}$ Understanding the Court's caseload and adjudicatory practices is crucial for devising solutions to many of the issues that will confront the Court in this reform exercise.

The remainder of the paper is organized as follows. Part I contains background for this study. Part II.A provides history and background on the Indian Supreme Court and explains the foundations of the Court as a court for the common person. Part II.B describes the origi-

${ }^{9}$ For example, Justice Bhagwati had called for the creation of a National Court of Appeal. Bihar Legal Support Society v. Chief Justice of India, AIR 1987 SC 38. In the Special Leave Petition (C) No. 7105 of 2010, March 19, 2010 for Mathai @ Joby v. George, (2010) 4 SCC 358, two Justices called for the Court to narrow Article 136 jurisdiction.

${ }^{10}$ Law Commission of India, 229th Report on the Need for division of the Supreme Court into a Constitution Bench at Delhi and Cassation Benches in Four Regions at Delhi, Chennai/Hyderabad, Kolkata and Mumbai (2009); T. R Andhyarujina, Restoring the Supreme Court's Exclusivity, The Hindu, Feb. 28, 2014, http://www.thehindu.com/opinion/lead/restoring-the-supremecourts-exclusivity/article5076293.ece; Nick Robinson, A Court Adrift, FrONTLINE, May 3, 2013; K.K Venugopal, For Proximate and Speedy Justice, The Hindu, May 2, 2010, http://www.thehindu.com/opinion/lead/for-proximate-andspeedy-justice/article418735.ece.

11 See Writ Petition (Civil) 36/2016, V Vasanthakumar v. HC Bhatia \& Ors. (petition to create a separate national court of appeals between the high courts and the Supreme Court).

12 See $i d$. 
nal dataset, including the process of collecting, processing, and validating the hand-coded information on nearly 5,000 judicial opinions. It also describes the conversations we had with judges, practitioners, and academicians in New Delhi in January 2016.

Part II uses our data and secondary sources to support the view that a significant focus of the Court's work is on case-by-case rescueindividualized justice rather than norm elaboration. Next, in Part IV, we argue that, given the Court's focus on individualized justice rather than norm elaboration, our data provide evidence that the Court gives priority of access to certain groups and certain categories of cases. These results call into question recent arguments that the Court favors powerful parties at the expense of underdogs, at least in relation to matters of access. Part V concludes with implications of our findings for some of the most pressing policy questions surrounding the Court in India today.

\section{BACKGROUND}

\section{A. Background on the Indian Supreme Court}

The Indian Supreme Court is the apex court for the largest common law judicial system in the world. In this Part, we provide an overview of the history and structure of the Indian judiciary in general and the Supreme Court in particular, highlighting its distinctive structure, membership, and scope of jurisdiction. We discuss the different means by which the Court may exercise original and appellate jurisdiction, some of which is discretionary and some of which is mandatory.

\section{History of the Court and Structure of the Judiciary}

India gained independence from colonial rule in 1947 and embarked upon the construction of a new political entity through drafting its own constitution. This constitution was shaped by the freedom struggle, influenced by constitutional developments around the world, and built on the extant administrative framework of the colonial era. The Indian constitution provides the blueprint for a rights-oriented, federal, secular, democratic polity. There is a separation of powers between a Westminster style parliamentary legislative wing, a powerful executive, and a strong judiciary. Learning from the American experience, the framers entrenched a bill of rights as well as judicial review in the constitution. 
The constitutional project, as envisaged by the framers, is not merely to delineate the structure of the state and define the relationship between citizen and state. Rather, the constitution has a selfavowed social goal-to be a vehicle for social transformation. ${ }^{13}$ Like many post-colonial constitutions, the Indian constitution seeks to bring about changes in the political, social and economic spheres in order to give effect to its vision of an egalitarian social order. ${ }^{14}$ As such, on the one hand the constitution guarantees a set of fundamental rights to life, liberty, and equality. On the other hand it also mandates that the state, through binding but judicially non-enforceable directive principles of state policy, work towards the realization of socio-economic justice. The constitution thus envisages an interventionist, welfare-oriented state.

The judiciary is intrinsic to furthering this constitutional vision. The constitution creates a broad three-tiered judicial system: district level civil and criminal trial courts, high courts, and the Supreme Court. ${ }^{15}$ High courts and the Supreme Court are constitutional courts empowered to issue writs for violations of constitutional rights and other constitutional provisions. They are also appellate courts in ordinary civil and criminal matters. The constitution envisages a unitary judicial court system such that all courts can examine and decide upon state as well as federal laws. Decisions of the Court are binding on all lower courts within the territory of India. ${ }^{16}$

The Supreme Court began functioning in 1950. Since that time, the Court has changed dramatically in size and structure. When the Court was formed in 1950, it had 8 judges to consider whether or not to admit 1,037 cases $^{17}$ and it issued 43 judgments. ${ }^{18}$ Since then, the Court has expanded in size to keep up with increasing demand. At present the Court has 31 seats, ${ }^{19}$ and it entertains over 60,000 appeals

13 Granville Austin, The Indian Constitution: Cornerstone of a Nation 27 (1966).

${ }^{14}$ India Const. art. 38.

15 Some high courts have jurisdiction over more than one state. Cumulatively, 24 high courts have jurisdiction over 35 states and union territories.

16 INDIA CONST. art. 141.

17 SuPREME COURT OF INDIA, ANNUAL REPORT 2014, at 76 (2015), http://sci.nic.in/annualreport/annualreport2014-15.pdf.

18 George H. Gadbois, Jr., "The Supreme Court of India: A Preliminary Report of an Empirical Study," Journal of Constitutional and Parliamentary Studies, Vol. IV, No. 1, Jan - March 1970 at 34.

19 INDIA CONST. art. $124, \S 1$. 
and petitions ${ }^{20}$ and issues approximately 1,000 judgments per year. ${ }^{21}$ While Court rules have never required judges to sit en banc, in the early years of the Court they would often do so.

2. The Court's Jurisdiction and Caseload

The Supreme Court has broad jurisdiction. First, under Article 32 of the Constitution, the power to move the Court to enforce fundamental rights is itself a guaranteed fundamental right. Dr. B. R. Ambedkar, the Chairperson of the Drafting Committee of the Constitution, called the power to directly invoke the Court's jurisdiction to claim fundamental rights "the very soul" of the Constitution, ${ }^{22}$ signaling the view that rights review is the core and primary function of the Court. The Supreme Court thus may sit as a court of original jurisdiction on any matter implicating fundamental rights. A party may invoke this (discretionary) power by filing a "writ petition" with the Court or the Court itself may initiate such proceedings on its own motion (suo moto, in the lexicon of the Court). ${ }^{23}$

One particularly distinctive component of the Court's original jurisdiction is public interest litigation ("PIL"), a judicially created innovation of the 1970s. Through PILs, the Court re-formulated standing rules to allow any member of the public to seek relief from the Court on behalf of a person or people whose fundamental rights had been violated but who could not, "by reason of poverty, helplessness or disability or socially or economically disadvantaged position," come before the Court for relief themselves. ${ }^{24}$

Second, the Court has discretionary appellate jurisdiction over any order passed by any court or tribunal across the country. A party seek-

20 SUPREME COURT OF INDIA, ANNUAL REPORT 2014, supra note 17, at 79.

21 JUDIS, the official e-reporter of the Supreme Court of India records 900 judgments for 2014.

22 Constituent Assembly Debates, Volume VII (Dec. 9, 1948).

23 See generally Marc Galantar, Snakes and Ladders: Suo Moto Intervention and the Indian Judiciary, 10 FIU L. REV. 69 (2014) (discussing instances of suo moto jurisdiction, chiefly by the Supreme Court of India).

${ }^{24}$ S.P. Gupta v. Union of India, AIR 1982 SC 149. The Court's own data reveals, however, that even among cases admitted for merits hearing, PILs constitute only $1 \%$ of the Court's cases (though, of course, given the complex nature of many PILs, they may take up a significant proportion of the Court's time and resources). Nick Robinson, A Quantitative Analysis of the Indian Supreme Court's Workload, 10 J. EMPIRICAL LEGAL STUD. 570, 590, 598 (2013). 
ing such discretionary review files a Special Leave Petition ("SLP"). Article 136 of the Constitution permits the Court to grant, at its discretion, "special leave to appeal from any judgment, decree, determination, sentence or order in any cause or matter passed or made by any court or tribunal in the territory of India." 25

Article 136 is broadly worded and gives the Court wide discretion to admit cases. ${ }^{26}$ The modern Court has interpreted Article 136 expansively and gives liberal access to the Court through these means. ${ }^{27}$ The Court will review lower courts decisions if miscarriages in justice arise from "some misapprehension or mistake in the reading of evidence or by ignoring material evidence." 28 This tendency appears to have grown somewhat over time. The proportion of "special leave petitions" in the Court's caseload rose from $78 \%$ to $82 \%$ in the 1990 s and from $83 \%$ to $86 \%$ between 2005 and $2011 .{ }^{29}$ In recent years, on average about 68,000 cases are filed annually before the Supreme Court, 30 most of which are SLPs.

${ }^{25}$ Kunhayammed v. State of Kerala, (2000) 6 SCC 359 ("Article 136 of the Constitution is a special jurisdiction conferred on the Supreme Court which is sweeping in its nature. It is a residuary power in the sense that it confers an appellate jurisdiction on the Supreme Court subject to the special leave being granted in such matters as may not be covered by the preceding articles. It is an overriding provision conferring a special jurisdiction providing for invoking of the appellate jurisdiction of Supreme Court not fettered by the sweep of preceding articles. Article 136 opens with a non-obstante clause and conveys a message that even in the field covered by the preceding articles, jurisdiction conferred by Article 136 is available to be exercised in an appropriate case.").

26 Jamshed Hormusji Wadia v. Board of Trustees, Port of Mumbai, AIR 2004 SC 1815.

27 As the Court itself has put it, it has stated that it has the power to interfere "even with findings of fact ... [as for example when] the acquittal is based on an irrelevant ground, or where the High Court allows itself to be deflected by red herrings drawn across the track, or where the evidence accepted by the trial court is rejected by the High Court after a perfunctory consideration, or where the baneful approach of the High Court has resulted in vital and crucial evidence being ignored, or for any such adequate reason, this Court may feel obliged to step in to secure the interests of justice, to appease the judicial conscience, as it were." Arunachalam v. P.S.R. Sadanatham, (1979) 2 SCC 297.

28 Subedar v. State of U.P., AIR 1971 SC 125.

29 See Nick Robinson, A Quantitative Analysis of the Indian Supreme Court's Workload, 10 J. EMPIRICAL LEGAL STUD. 570, 598 (2013).

30 SUPREME COURT OF INDIA, ANNUAL REPORT 2014, supra note 17, at 76-79 (average of cases filed in 2010-14). 
Although such a broad approach to SLP jurisdiction has been criticized from time to time, even by members of the Court itself, 31 it remains the norm. In early 2016 a Constitution Bench of the Supreme Court declined to lay down guidelines for exercise of the Article 136 jurisdiction, holding instead that "no effort should be made to restrict the powers of this Court under Article 136 because while exercising its powers under Article 136 of the Constitution of India, this Court can, after considering facts of the case to be decided, very well use its discretion." 32

Third, the Court also hears cases certified for appeal by High Courts. ${ }^{33}$ Further, many statutes provide for a statutory right to appeal to the Court. ${ }^{34}$ Appeals as of right are defined by statute for certain claims heard by lower courts and well as for review of decisions by specialized tribunals-adjudicatory bodies separate from the Indian court system that resolve statutory claims in specialized fields, such as electricity regulation, customs and excise, or statutory consumer protection.

The Court thus performs a dual function: as a court of original jurisdiction on certain matters such as those relating to the enforcement of fundamental rights; and as a final court of appeal against decisions and orders passed by subordinate courts and tribunals. ${ }^{35}$

31 Bihar Legal Support Society v. Chief Justice of India, AIR 1987 SC 38 (stating the view that cases under Article 136 "would be exceptional by their very nature" and that the Court should not interfere in every case where "some injustice has been done."). See also Jamshed Hormusji Wadia v. Board of Trustees, Port of Mumbai, AIR 2004 SC 1815; Chandi Prasad Chokhani v. State of Bihar, AIR 1961 SC 1708; State of Bombay v. Rusy Mistry, AIR 1960 SC 391; Pritam Singh v. State, AIR 1950 SC 169.

32 Mathai @ Joby v. George, 2016 SCC OnLine SC 410.

${ }^{33}$ INDIA ConsT. art. 132, 133, 134. Although the Court's jurisdiction can be invoked through procuring a certificate of appeal from the high court, this practice is rarely used. One possible reason for the low use of the "Certificate of Appeal" jurisdiction is that while ordinarily a petitioner has 90 days to file a SLP, the limitation for filing a SLP after the high court has refused a certificate of appeal is 60 days. Some experts suggested during interviews and interactions with us that lawyers do not invoke the certificate of appeal process so as to give themselves more time to file in the Supreme Court.

34 Supreme Court of India, Annual Report 2014, supra note 17, at 59-63.

35 This is not the limit of the Court's jurisdiction. The Supreme Court has original jurisdiction with respect to inter-state disputes over certain election matters. INDIA CONST. art. $132 \& 711$. The President may also refer any matter to the Court for its advisory (non-binding) opinion. INDIA CONST. art. 143. 


\section{Admissions Process}

To decide which matters to admit, judges sit in benches of two and hear about 67 cases per bench every Monday and 50 every Friday. ${ }^{36}$ To go through so many cases in a single day, on average judges hear each matter for an extremely short duration-perhaps a few minutes. The admissions hearing is an ex parte proceeding, and the Court denies most SLPs at the admissions stage. While most denials are in fact concluded ex parte, admissions generally occur only after the Court, being inclined to admit, issues notice to the other side to appear. Parties can also preemptively file a "caveat" in the Court, requesting that no petition be admitted in which it is a respondent without the presence of such party. In such cases, a matter is listed for admission only after notice is served to the other party. Very rarely does the Court admit a matter ex parte. Of the matters in which notice is issued, the Court may dispose of the matter at the admissions stage itself (called "final disposal" matters). In such cases, after a brief hearing, if the Court admits the matter, it allows or denies the SLP as part of the same order. Where the Court finds the need for a more extensive hearing, the case is listed for a "regular" merits hearing.

\section{The Court from 2010-2014}

During the period that our data set covers, 2010-2014, six judges held the post of Chief Justice of India. Thirty judges were appointed to the Court in this time period, of which three were women. A total of 342,806 matters were filed for admission in this duration, at an annual rate of 68,516 matters per year. ${ }^{37}$ Of these, 1,021 matters were writ petitions for the enforcement of fundamental rights. ${ }^{38}$

\section{Docket Explosion and Lengthy Disposition Times}

It is well known that cases can take decades to resolve within the Indian judicial system. Decrying this phenomena, human rights advocates argue that lengthy court delays deny justice and invoke the re-

36 Supreme Court of India, Practice and Procedure: A Handbook of Information 35 (2010).

37 SUPREMe COURT OF INDIA, ANNUAL REPORT 2014, supra note 17, at 76-79. Data available up to November 2014.

${ }^{38} \mathrm{Id}$. at 63-64. This data is available only up to October 31, 2014. 
frain that "justice delayed is justice denied."39 Economists and business people have also raised the alarm on delays because they believe lengthy case disposition times inhibit investment by foreign companies and have other negative impacts on economic growth. ${ }^{40}$ Often judges are blamed for taking too long to decide cases, but even if this were true this could only be part of the explanation.

The sheer increase in the number of cases filed across all courts in India is a large part of the explanation for lengthy court delays. Although the number of judges to the Court has increased over time, it has not kept up with the pace of litigation. The number of admission matters doubled from 1993 to 2011 from 24,747 to 48,677. ${ }^{41}$

Our data set gives us insights into the length of time cases take at each stage in the judicial system. In the Court itself, the cases in our sample have an average elapsed time from the date of decision by the court below to the date of decision by the Supreme Court of 1,542 days. ${ }^{42}$ This is more than 4 years and 2 months. ${ }^{43}$ (This may be surprising to those who believe it is the lower courts that are the laggards in the court system.) And these are the cases that have been decided; the elapsed duration of admitted cases that remain pending is another question altogether. ${ }^{44}$

To get a better sense of the length of case disposition in the Supreme Court relative to that of the lower courts, we focus on those $\mathrm{Su}$ preme Court judgments whose procedural history is stated in sufficient detail for us to reconstruct the amount of time the case spent in the court of first instance, on appeal before reaching the Supreme Court, and in the Supreme Court. There are only 123 such cases in our data, and there is no guarantee that they are representative of the whole. With that caveat, the average duration for these cases from filing in the court of first instance to a merits decision by the Supreme

39 See, e.g., Nathan Rehn et al., Ctr. on Pub. Law \& Jurisprudence, Jindal Glob. Law Sch., Justice Without Delay: Recommendations for Legal and Institutional Reforms in Indian Courts (Jindal Global Legal Research Paper No. 4/2011, 2010).

40 Simi Rose George, Releasing India's Supreme Court from the Shadow of Delay: A Proposal for Reform 6 (Mar. 16, 2014) (masters thesis, Harvard University), https://www.hks.harvard.edu/index.php/content/download/66823/ 1240102/version/1/file/SYPA_SimiGeorge_2014.pdf.

${ }^{41} I d$. at $2-3$. From 2005 to 2011 , lower court disposals grew only by $7.8 \%$. Id. at 16.

${ }^{42}$ See Table 1.

${ }^{43}$ The median is not much better. It is 1,260 days, or 3 years and 5 months.

${ }^{44} \mathrm{We}$ are currently gathering data that may shed light on this. 
Court was 4,921 days, or 13 years and 6 months. ${ }^{45}$ The Court accounts for about one-third of this total. See Figure 1 for the means across levels of the court system, and Figure 2 for medians. ${ }^{46}$

Figure 1. Mean (Average) Duration in Each Court, Cases With COMPLETE HISTORY

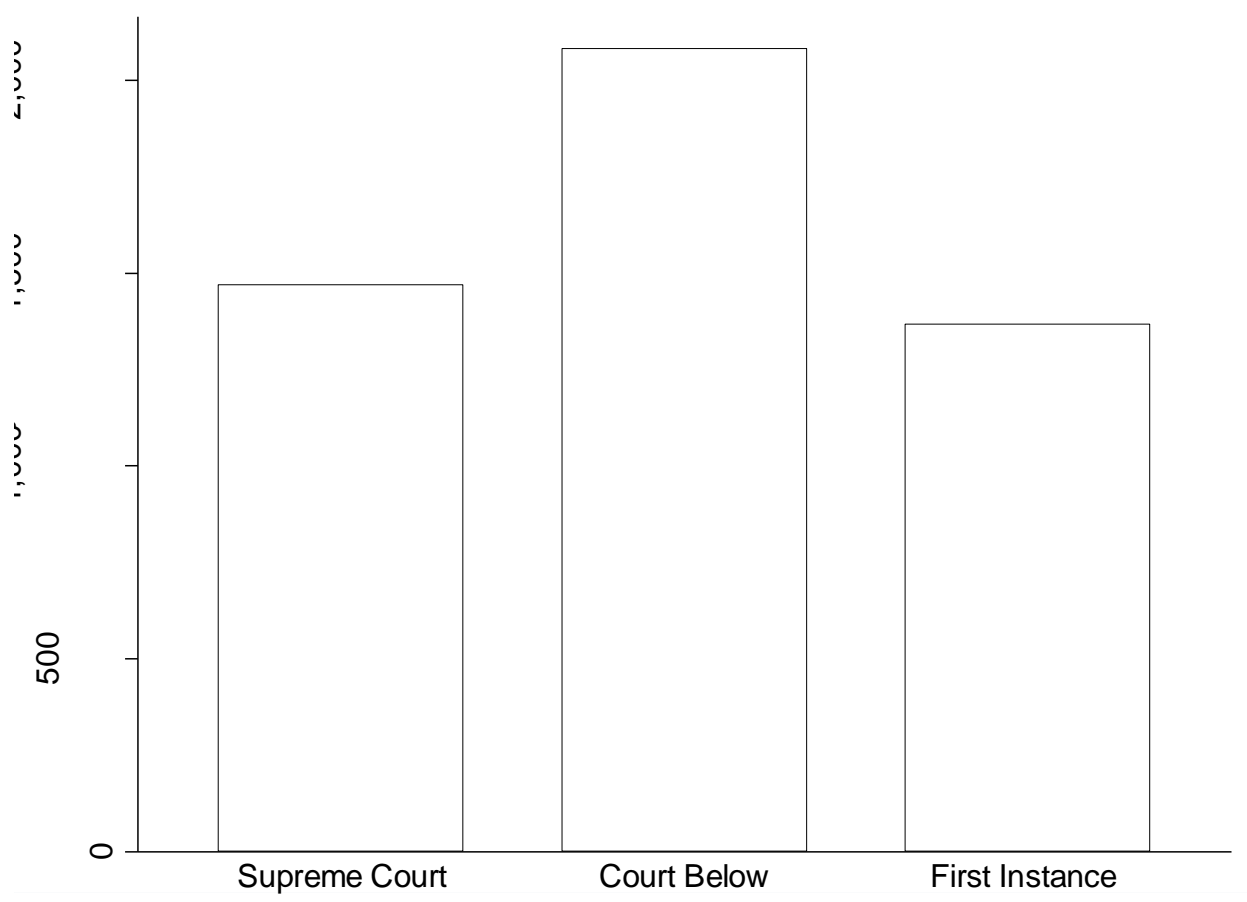

45 The median case duration is 4,231 days, or 11 years and 7 months. 46 The Court's share of the total in this subset of 123 cases is comparable to of its share among all cases. See Table 1. 
Figure 2. Median Duration in Each Court, Cases With Complete HISTORY

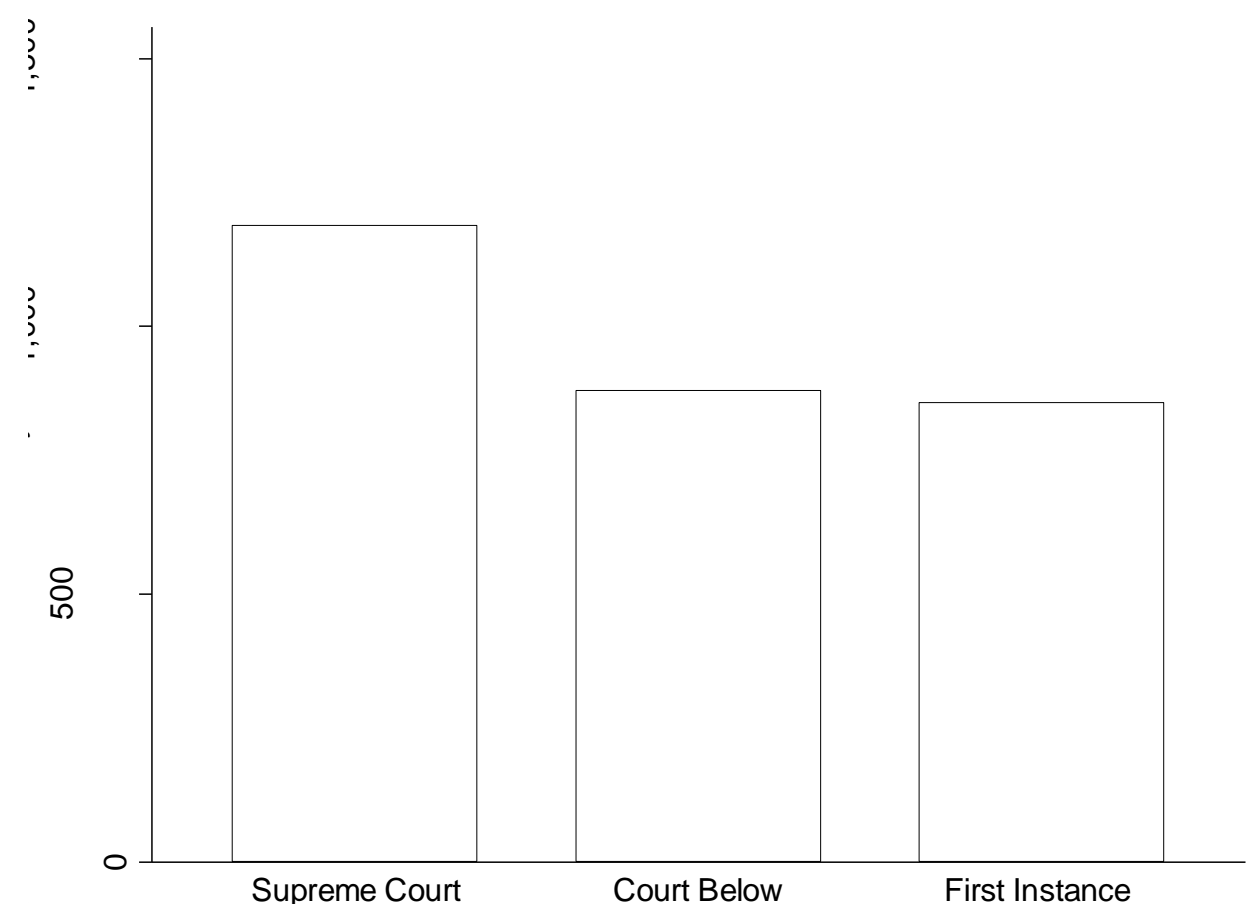

\section{B. Our Data}

Our dataset of Court judgments is the product of a multi-year project to collect, review, hand-code, quality-check, and then analyze a comprehensive set of published opinions of the Court. The dataset of Court judgments currently stands at 4,834 judgments from 2010 to 2014. This project involved five roughly sequential elements: (1) selection of source material for Court opinions; (2) initial development of a template for hand-coding, and pilot testing, review, and revision of the template; (3) comprehensive hand-coding of all cases within the sample frame; (4) processing and quality control; and (5) creation of the final database for analysis.

First, we selected the Supreme Court Cases ("SCC") reporter as the source for the judicial opinions that we would code. SCC is the 
most cited reporter by and before the Supreme Court. ${ }^{47}$ Since SCC is a private reporter, it is under no obligation to publish every decision given by the Supreme Court. However, it is easily accessible, has extensive headnotes, and unlike other reporters, records many details, including the names and designations of lawyers involved.

Second, we developed an initial template identifying variables of interest that our research team could extract from written opinions of the Court. The template took the form of an Excel spreadsheet with variable descriptions that coders would use. Using this template, a group of student coders at Cornell Law School began coding cases for the year 2010. Coders read the full text of each Court opinion and completed the coding of each case based on that text. For purposes of the initial coding done by Cornell Law students, we used the judgments published on the Court's website, known as JUDIS. ${ }^{48}$ We then reviewed the results of this pilot effort to identify variables that could not be reliably coded, coding instructions that needed revision to remove ambiguities, and the like. This resulted in a major overhaul of the template, including the creation of detailed drop-down menus for variables that could be coded categorically. The new template became the master template for coding of the entire sample frame; to ensure internal consistency within the final dataset, we discarded the results of the pilot coding phase.

Third, we assembled a team of nearly two-dozen students from $\mathrm{Na}$ tional Law University, Delhi, who then took up the task of coding cases. The team read judicial opinions from the SCC Reporter and completed Excel templates. The Delhi team hand-coded all cases reported in SCC in its volumes for the years 2010 to 2014. Cases reported in these volumes that were decided prior to 2010 were excluded from consideration. Each case was coded for 66 variables (although we do not use all coded variables in our analysis herein). A full list of the hand-coded variables with detailed descriptions appears in Appendix A.

Fourth, the team of coders at NLU Delhi worked with researchers at the University of Chicago Law School to identify and correct errors and discrepancies in coding across cases. This iterative process in-

${ }^{47}$ Rakesh Kumar Srivastava, A Guide to India's Legal Research and Legal System, GLOBALEX (April 2014), http://www.nyulawglobal.org/globalex/india_legal_research.htm\#_10._Law_R eporting (Chief Librarian of the Supreme Court, stating that this reporter is used around $60 \%$ of the time before the Supreme Court itself).
48
JUDGMENT
INFORMATION
SYSTEM
(JUDIS),

http://judis.nic.in/supremecourt/chejudis.asp. 
volved statistical analysis of the coded data to identify inconsistencies in coding patterns across variables. This primarily consisted of items being entered inconsistently by coders, due to spelling errors or the use of abbreviations by some coders but not others. ${ }^{49}$ These inconsistencies were documented by the research team and corrected through an automated recoding process to make codes consistent across cases. ${ }^{50}$ In other cases, review by the authors (and coders themselves) revealed that different coders had coded certain questions differently. For example, some coders had treated the "court of first instance" as the first court in which a formal, judicial complaint had been filed, while others would treat an internal inquiry of a government agency as the court of first instance. In such cases, the coders returned to the original cases and recoded them by hand under a consistent rule. ${ }^{51}$

Fifth and finally, the cleaned and processed data was converted to the Stata database format for statistical analysis. The dataset includes all Court judgments from 2010 through 2014 that have been published in the SCC, with the exception of orders from one-judge benches. 52

Because our analysis focuses on how the Court chooses to exercise its discretionary, appellate jurisdiction, the statistics we report in this paper exclude cases within the original jurisdiction of the Court. ${ }^{53}$ Summary statistics for this paper's dataset appear in Tables 1, 2 and

${ }^{49}$ For most variables, such discrepancies were avoided through the use of prefilled drop-down menus that allowed coders to choose among multiple options. Some variables needed to option for coders to enter unique text, however.

50 Computer code documenting these corrections is available upon request.

${ }^{51}$ In the end, some variables had to be dropped from the final dataset altogether because, even after review by the research team, the number of unique entries could not be simplified in a manner suitable for quantitative analysis. 52 We excluded one-judge benches because they generally deal with procedural matters, such as certain types of minor interim applications, which do not generate merits judgments (although they occasionally generate orders that appear in SCC). We also exclude cases with missing information on which party was appellant or information civil or criminal subject matter, and we exclude PIL cases and continuing mandamus cases, which represent important but very distinct segments on the Supreme Court's docket.

${ }^{53}$ Ideally, we would simply include only those cases that reached the Court through the SLP process. In processing the data, however, we discovered that this is not currently feasible. When the Court admits an SLP for a separate merits hearing, the administrative office of the Court converts the case designation from "SLP" to "appeal," which is also used to designate cases that reach a merits hearing by appeal as of right. 
3. Additional summary statistics appear in later sections, where the data is specifically relevant.

TABLE 1. Summary Statistics, CONTINUOUs VARIABLES ${ }^{54}$

\begin{tabular}{lccccc}
\hline \multicolumn{1}{c}{ Variable } & Mean & Median & Max & Min & N \\
\hline $\begin{array}{l}\text { Year Decided by } \\
\text { Supreme Court }\end{array}$ & 2012 & 2012 & 2014 & 2010 & 4146 \\
$\begin{array}{l}\text { Duration in Court of } \\
\text { First Instance (Days) }\end{array}$ & 1345 & 847 & 8165 & 0 & 129 \\
$\begin{array}{l}\text { Duration in Intermedi- } \\
\text { ate Court (Days) }\end{array}$ & 1794 & 998 & 16574 & 0 & 1500 \\
$\begin{array}{l}\text { Duration in Supreme } \\
\text { Court (Days) }\end{array}$ & 1542 & 1260 & 12404 & 0 & 3748 \\
$\begin{array}{l}\text { Number of Pages in } \\
\text { Opinion }\end{array}$ & 9.7 & 7 & 330 & 1 & 4098 \\
\hline
\end{tabular}

To provide ourselves with context and qualitative feedback on our hypotheses, we conducted interviews with various stakeholders before the Supreme Court. In January 2016 we met with current and retired judges of the Supreme Court, officials of the Supreme Court Registry, senior advocates and academicians both to clarify doubts on aspects of the functioning of the Court, as well as to obtain their substantive inputs on the role and functions of the Court. In addition, we presented preliminary data from the project at a consultation at the University of Chicago Center in Delhi, and received feedback from an audience

${ }^{54}$ Note that the number of observations (" $N$ ") for each variable is different. This is because not every case contained information that allowed coders to record information for every variable. For example, "Duration in Court of First Instance (Days)" has only 129 non-missing observations, because relatively few Supreme Court opinions mentioned both the date of filing and the date of judgment in the court of first instance. 
consisting mostly of lawyers practicing before the Court and academics. ${ }^{55}$ We note that there was broad agreement in our conversations with the claims we make below (that the Court gives greater access to individuals in civil cases, defendants in criminal cases, and parties raising constitutional claims).

TABLE 2. SUMMARY STATISTICS, INDICATOR VARIABLES

\begin{tabular}{lcc}
\hline \multicolumn{1}{c}{ Variable } & Percent & $\mathrm{N}$ \\
\hline Reversed or Remanded & $57.2 \%$ & 4002 \\
Petitioner is Plaintiff & $45.4 \%$ & 3959 \\
& & \\
Original Plaintiff Wins & $48.3 \%$ & 3860 \\
& & \\
Case Originated in Tribunal & $15.4 \%$ & 4108 \\
& & \\
Criminal Case & $34.0 \%$ & 4146 \\
& & \\
Constitutional Challenge & $3.9 \%$ & 4143 \\
Constitutional Challenge & & \\
Success Rate & & 156 \\
Lower Courts Agreed (High & & \\
Court Affirmed Trial Court) & & \\
Precedent Overruled & $3.8 \%$ & 4123 \\
Parties to Bear Own Costs & $64.5 \%$ & 2334 \\
\hline
\end{tabular}

55 The consultation took place on 16 January 2016. 


\section{THE CASE-BY-CASE RESCUE COURT}

It is fairly well established that the modern Indian Supreme Court does not limit its work to norm elaboration, particularly in respect of the Article 136 jurisdiction (special leave petitions). The Court will intervene in a case and reverse the lower court decision if it disagrees with the outcome below regardless of whether or not it is resolving a conflicting norm, articulating a new norm, or overturning a norm. ${ }^{56}$ We do not argue that the Court does not elaborate norms, but point out that a large portion of its workload is focused on error correction.

The empirical analysis presented in a recent article by Andrew Green and Albert Yoon supports our view of the modern Court as one that spends a significant amount of its time engaging in error correction. In examining every decision of the Supreme Court published in Westlaw India from 1950 to 2010, the authors found that in the mid1990s the number of cases cited by the Supreme Court in its opinions declined dramatically and is only about a quarter of the average number of cases cited by another common law court, the United States Supreme Court. ${ }^{57}$ They also examined the top 100 cases annually that had the most citations (based on their "hub score") and found that the top 100 cases actually had an increasing number of citations over time. ${ }^{58}$

Consequently, the authors conclude that "the Indian Supreme Court may then have two very different sets of cases or modes of decision-making to deal with the high caseload. For a large percentage of cases, the Court does not cite any prior case, and when it does, it does not cite many." 59 The authors find that the judges do, however, "engage in search and citation practice in a small set of cases" and in each of those cases "they on average cite a fair number of former decisions." 60

These findings are consistent with our assumptions and data. First, we would expect that a court that is concerned about case-by-

${ }^{56}$ See generally, Mathai @ Joby v. George (2010) 4 SCC 358.

57 Andrew Green and Albert Yoon, Triaging The Law: Developing the Common Law on the Indian Supreme Court, July 23, 2016, unpublished draft available on SSRN, https://papers.ssrn.com/sol3/papers.cfm?abstract_id=2816666, pages 6, 12, and 13.

58 Id at page 15.

${ }^{59} \mathrm{Id}$ at pages 15 to 16 .

$60 \mathrm{Id}$ at p. 16. 
case rescue will have a more liberal access policy than a court that has a greater focus on norm-elaboration. Indeed, of the 342,417 admissions decisions by the Court from 2010 to 2014, 47,806 were admitted for regular hearing. While, in the absence of a benchmark, it is difficult to know whether this admission rate is high or low, it is instructive to note that by comparison the U.S. Supreme Court-an avowedly norm elaborating court-admits about $1 \%$ of all cases seeking admission while the Supreme Court of India admits $14 \%$ of its petitions. ${ }^{61} \mathrm{~A}$ more liberal access is consistent with a court whose goal is to correct all kinds of errors made by lower courts rather than just errors that involve norm-elaboration.

Second, the sheer volume of cases the Court adjudicates each year suggests that its goal is to correct errors case-by-case. The Court generates nearly 1000 written opinions on merits per year, averaging 10 pages each in length. ${ }^{62}$ Common sense suggests it is not creating new common law rules in all or most of these cases. It is beyond the scope of this paper to elaborate on this observation, but we will merely note here that such prodigious output-which is surely a testament to the work ethic of the justices of the Court-may be a force for confusion rather than clarification in the Court's jurisprudence, as other scholars have hypothesized. 63

61 Frequently Asked Questions (FAQ), SUPREME COURT OF THE UNITED STATES, https://www.supremecourt.gov/faq.aspx (last visited Aug. 30, 2016) (answering "How many cases are appealed to the Court each year and how many cases does the Court hear?" with "The Court receives approximately 7,000-8,000 petitions for a writ of certiorari each Term. The Court grants and hears oral argument in about 80 cases."). Of course, we understand that the structure of the Indian judiciary and American judiciary differ. While each state in the U.S. has its own supreme court that has exclusive jurisdiction over certain matters, the Indian judiciary is a unitary system where appeals from most courts would come to the Supreme Court eventually. Yet, this difference does not explain why the rate at which the Indian Supreme Court admits the cases that are appealed to it is so much higher than the rate at which the U.S. Supreme Court admits the cases that seek admission.

62 For statistics on SLPs and appeals, see Table 1. (The total number of opinions per year is greater than listed in Table 1, due to cases within the Court's original jurisdiction.) Note that the 10-page average length is inclusive of all opinions for a given case.

${ }^{63}$ See generally Rishad Chowdhury, Note, Missing the Wood for the Trees: The Unseen Crisis in the Supreme Court, 5 NUJS L. REV. 251 (2012); Nick Robinson, India's Judicial Architecture, in THE OXFORD HANDBOOK OF INDIAN CONSTITUTIONAL LAW (Sujit Choudhry et al. eds., 2016). 
TABLE 3: SummaRy StATistics, By BenCH SizE64

\begin{tabular}{|c|c|c|c|c|}
\hline Bench Size & 2 & 3 & 5 & Total \\
\hline Total Cases & 3841 & 264 & 38 & 4143 \\
\hline Share of Total & $92.7 \%$ & $6.4 \%$ & $0.9 \%$ & $100 \%$ \\
\hline $\begin{array}{l}\text { Number (Share) of } \\
\text { Cases with Const. } \\
\text { Challenge }\end{array}$ & $\begin{array}{r}134 \\
(3.5 \%)\end{array}$ & $\begin{array}{r}18 \\
(6.8 \%)\end{array}$ & $\begin{array}{r}11 \\
(29.0 \%)\end{array}$ & $\begin{array}{r}163 \\
(3.9 \%)\end{array}$ \\
\hline $\begin{array}{l}\text { Number (Share) of } \\
\text { Challenges that } \\
\text { Were Successful }\end{array}$ & $\begin{array}{r}53 \\
(40.5 \%)\end{array}$ & $\begin{array}{r}10 \\
(55.6 \%)\end{array}$ & $\begin{array}{r}7 \\
(77.8 \%)\end{array}$ & $\begin{array}{r}70 \\
(42.9 \%)\end{array}$ \\
\hline $\begin{array}{l}\text { Cases Striking } \\
\text { Down Legislation }\end{array}$ & 14 & 4 & 1 & 19 \\
\hline
\end{tabular}

Third, based on the results of our coding of the data, there are several indications that while the Court entertains norm-elaboration cases, there are significantly fewer of them than error-correcting cases. As Table 3 shows, during the period of our data set (2010 to 2014), nearly $93 \%$ of appeals were heard by benches consisting of two judges. Procedurally, only benches of three judges can reverse benches of two judges and so on. The fact that they sit in small benches so frequently suggests that either they are not overturning common law rules (since that would require larger benches) or are doing so in disregard of procedural norms. A Court focused on norm elaboration is likely to favor for admission cases which call for reexamination of previously established norms. It follows that such a court would overrule (or at least modify) precedent in a significant proportion of the cases that it undertakes. However, the Court only overruled precedent in less than $4 \%$ of the cases in our data set. Of course, overruling precedent is not the only means of norm elaboration. However, such a low rate of overruling suggests that by and large the Court is not concerned with norm reevaluation. As we also see in Table 3, constitutional matters (where one might expect more norm-elaboration cases) form a very

64 Percentages may not add up to $100 \%$ due to rounding. 
small part of the Court's output, comprising only $4 \%$ of all decisions in our dataset.

Fourth, there are numerous examples of cases where the Court appears to be simply re-examining how a lower court has resolved a dispute. It admits even cases that involve a determination of the proper amount of bail in a criminal case or whether or not to grant a divorce. Take, for example, the case of Y.S. Jagan Mohan Reddy $v$. $C B I .{ }^{65}$ Reddy, a Member of Parliament, was accused of various offences relating to corruption. He was arrested pending completion of the investigation and trial. He sought bail from the trial court as well as the high court, but his application was rejected by both fora. On appeal before the Supreme Court, the only question before the Court was whether bail should be granted or not. The Court admitted the appeal and in its decision described the charges against Reddy and the concerns raised by the investigating authority that if Reddy were out on bail he could hamper investigation. On the basis of "all these facts and the huge magnitude of the case and also the request of the [investigating authority] asking for further time for completion of the investigation" the Court decided to grant bail. Of note is the fact that the entire discussion revolved only around the facts of the case. The decision in Reddy follows a common pattern in bail matters decided by the Court where the Court the court does not discuss any law or cite any precedent. 66

Take another example, this time of a case of divorce. Darshan Gupta filed for divorce against his wife Radhika Gupta, alleging that she had treated him with cruelty and was of unsound mind, both grounds for divorce under the applicable law. 67 The Family Court rejected these contentions and refused to grant divorce. The High Court upheld the lower court's decision. On appeal before the Supreme Court, the Court admitted the matter, and sought to reach an amicable settlement between the parties. When that failed, it decided the case on merits. In its entire decision, the Court narrated the procedural history of the case and evidence recorded by the lower courts. It then proceeded to give its own assessment of whether the facts made out a case for cruelty and whether Darshan Gupta had succeeded in proving that his wife was of unsound mind. This discussion took place

65 Y.S. Jagan Mohan Reddy v. CBI, (2013) 7 SCC 439.

66 See, e.g,, Maruti Nivrutti Navale v. State of Maharashtra, (2012) 9 SCC 235; Jignesh v. State of Gujarat, (2011) 10 SCC 591 (both pertaining to bail where the Court decided-without reference to or discussion of any prior law-whether, on the facts of the case, bail was warranted or not).

${ }^{67}$ Darshan Gupta v. Radhika Gupta, (2013) 9 SCC 1. 
without any reference to what constitutes cruelty or the standards for assessment of whether a person is of unsound mind. In the entire judgment, the only discussion on law took place when one party argued that despite the law not supporting divorce in the case, the Court should exercise its power to do "complete justice" between parties 68 to dissolve the marriage in any case. This plea was rejected on the ground that the facts of the case were not suited to the exercise of such power by the Court. In the end, based on its assessment the Court upheld the decision of the lower courts. Again, this case is not an uncommon instance. ${ }^{69}$ Justices of the Court have themselves acknowledged that the Court often acts like an "ordinary forum of appeal,"70 "leaping into resolution of individual controversies once it has been brought to its notice that the case has failed to deliver substantial justice."71

Finally, while we make no claim to have interviewed a representative sample of current and former Supreme Court justices, high court judges, senior advocates, and scholars, those whom we did interview expressed a striking consensus both that the Court behaves as if it had the intent to intervene wherever it perceives an "unjust" outcome in a lower court (regardless of the presence or absence of legal error or precedential value) and that at least some members of the Court expressly avow that this is in fact their intent when they make the decision to admit a case for a hearing on the merits. In one of its own judgments, the Court observed that it admits cases if lower courts have "failed to deliver substantial justice or [have] perpetuated grave injustice to parties or is one which shocks the conscience of the Court or suffers on account of disregard to the form of legal process or with violation of the principles of natural justice."72 Observations such as these lead us to the conclusion that the Court is routinely examining cases to determine whether the Court agrees with the outcome below,

68 INDIA CONST. art. 142.

69 See, e.g., Ramchander v. Ananta, (2015) 11 SCC 539; K. Srinivas v. K. Sunita, (2014) 16 SCC 34; Alok Mishra v. Garima Mishra, (2009) 12 SCC 270 (deciding whether or not the lower court was right in granting divorce, approving the terms of settlement in a divorce by mutual consent and deciding whether lower courts made the correct decision on custody of minor children).

70 Mathai @ Joby v. George (2010) 4 SCC 358.

71 Jamshed Hormusji Wadia v. Board of Trustees, Port of Mumbai, AIR 2004 SC 1815.

72 Jamshed Hormusji Wadia v. Board of Trustees, Port of Mumbai, AIR 2004 SC 1815. 
rather than to determine whether the norms applied need to be revised.

Thus, we assume that one of the important goals the Supreme Court justices when they make admissions decisions is to identify cases where the lower court has made an error in facts or application of facts to law. Again, we note that when we speak of the Court's behavior we are hypothesizing based on this premise only that the Court's behavior on average will be consistent with this model of the Court. Individual justices may have approaches that deviate from this norm.

\section{CASE-BY-CASE RESCUE FOR THE COMMON PERSON}

Having noted that the Court is engaged in individualized error correction in its SLP docket, we address whether, while doing this, the Court gives priority to the "common person."

Recent research and commentary has called this self-image of the Court into question. Balakrishnan Rajagopal argues that the Court increasingly shows a bias against impoverished persons. ${ }^{73}$ Citing cases arising after the 1990s, Manoj Mate argues that the Court's rulings favor corporations and business interests when they claim fundamental rights violations, but against labor interests and other stakeholders whose claims might challenge globalization and economic liberalization. ${ }^{74}$ Varun Gauri uses empirical analysis to argue that the Court increasingly disfavors disadvantaged groups. ${ }^{75}$

On the other hand, Sudhir Krishnaswamy and Madhav Khosla question the view that the court has generally moved in a conservative direction. ${ }^{76}$ In critiquing the empirical work by Shylashri Shankar, Krishnaswamy and Khosla pointed out that one of the reasons Shan-

73 Balakrishnan Rajagopal, Pro-Human Rights but Anti-Poor? A Critical Evaluation of the Indian Supreme Court from a Social Movement Perspective, 18 HUM. RTS. REV. 157, 166-68 (2007).

${ }^{74}$ Globalization, Rights, and Judicial Review in the Supreme Court of India, 25 Wash. Intl'L L.J. 643 (2016).

75 Varun Gauri, Public Interest Litigation in India: Overreaching or Underachieving? P. 13 (World Bank, Policy Research Working Paper No. 5109, 2009), available at

http://documents.worldbank.org/curated/en/675001468042007347/pdf/WPS51 09.pdf

${ }^{76}$ Sudhir Krishnaswamy \& Madhav Khosla, Social Justice and the Supreme Court, in THE SHIFTING SCALES OF JUSTICE: THE SUPREME COURT IN NEO-LIBERAL INDIA 109, 110 (Mayur Suresh \& Siddharth Narrain eds., 2014). 
kar may have observed lower win rates over time for certain types of cases may reflect something about the admissions process. Specifically, they note that "the higher rejection rate may well be the result of the admission of a higher number of cases which are poorly drafted or pleaded." 77 In other words, they suggest that the Court may be taking weaker cases from certain groups and that is why those groups have a lower win rate. We build on this intuition and the logic of the "hit-rate analysis" to argue that a lower win rate for one group as compared to a another group does actually reflect the admission of weaker cases from the group with the lower win rate.

Our goal here is not to determine whether the Court is less activist vis-à-vis the executive or more activist over the years, nor it is to make a claim about whether its decisions are pro-business or conservative in other respects. Instead, we seek to determine whether the Court in recent years has acted like a court for the common person as it was envisioned to be when it was founded. We hypothesize that a court that acts like a court for the common person is likely to favor for access individuals over the government in civil cases, defendants over prosecutors in criminal cases, and cases raising constitutional challenges over cases raising other issues. In the absence of data regarding the social identities and histories of parties, we are using their relative power vis-à-vis the opposite party as a proxy for evaluating the Court's priorities.

We use a "hit-rate methodology" to argue that patterns in our data on the Court's judgments can shed light on whether the Court is favoring certain groups for admission of their SLPs. We emphasize that our analysis is focused strictly on the Court's appellate docket, and specifically SLPs. We conclude that the Indian Supreme Court does, in fact, give more access to categories of litigants largely in line with its mission to provide justice for the common person.

A. Justifying the Hit-Rate Methodology

Our analysis draws from the hit-rate methodology developed in empirical scholarship on racial profiling. In one famous study, data revealed that police officers in a particular area were more likely to stop African-American drivers than Caucasian-American drivers when searching for drugs, but the police were equally likely to be successful

77 Sudhir Krishnaswamy \& Madhav Khosla, Social Justice and the Supreme Court, in THE SHIFTING SCALES OF JUSTICE: THE SUPREME COURT IN NEO-LIBERAL INDIA 111 (Mayur Suresh \& Siddharth Narrain eds., 2014). 
in finding illegal substances on African-American drivers they stopped as on Caucasian-American drivers. From this, the authors concluded that police officers appeared to be motivated by a desire to maximize the number of searches that found drugs, and that the higher rate of stops for African-Americans did not reflect animus based on race. ${ }^{78}$ Other studies, it is worth noting, reached different conclusions based on different data from different areas and different types of police activity. Regardless of the ultimate findings on police bias, the key idea from this literature is that if the police are focused on finding lawbreaking (i.e., "error correction") then we should see equal hit-rates (i.e., "reversal rates") across different groups that are being investigated (i.e., different types of "cases"). 79

One should expect a court that is focused on case-by-case rescue to make an initial assessment at the admission stage about whether or not an error has occurred. ${ }^{80}$ By admitting for hearing (and therefore possible reversal) only those cases with the highest perceived likelihood of reversal, the court will, on average, maximize the number of errors it can correct. Given its finite resources in terms of time and

78 The best-known paper on this method is John Knowles, Nicola Persico \& Petra Todd, Racial Bias in Motor Vehicle Searches: Theory and Evidence, 109 J. Pol. Econ. 203 (2001). Notable critiques and extensions include Dhammika Dharmapala \& Stephen L. Ross, Racial Bias in Motor Vehicle Searches: Additional Theory and Evidence, 3 Contributions to Econ. Analysis \& Pol'y 1 (2004), and Shamena Anwar and Hanming Fang, An Alternative Test of Racial Prejudice in Motor Vehicle Searches: Theory and Evidence, 96 Am. Econ. Rev. 127 (2006). See Nicola Persico, Racial Profiling? Detecting Bias Using Statistical Evidence, 1 Ann. Rev. Econ. 229 (2009), for a review.

79 This pattern also depends on an additional assumption, which is that all citizens (or cases) are "marginal," in the sense that in equilibrium they adjust their behavior to the behavior of the police (or the Court). Another more intuitive but less theoretically grounded version of this assumption is that the distribution of behavior across types (e.g., citizens of different races or petitions brought by different parties) is similar. In this paper, we assume that cases that have made their way through the litigation and appellate process and to the Supreme Court have roughly similar distribution of cases across those that are highly likely to be reversed, moderately likely to be reversed, and so on. In Appendix B, we offer evidence suggesting that this assumption may hold for our data.

80 It bears repeating that when we refer to "errors," we mean anything that would lead the Court to reverse the judgment below, regardless of whether there was a misapplication of law or whether any observer would agree with the Court's decision. This approach simply accepts the Court's definition of error in any given case. 
attention and the huge crush of cases seeking review, the Court would prefer to use its discretion at the admissions stage to take only those cases most likely to require reversal. Ideally, then, among all the various categories of cases coming to it, the court will take those most likely to be reversed, such that all cases with a likelihood of reversal above some cutoff percentage will be admitted, and all petitions below that threshold will be denied admission.

The better a court's ability to identify errors at the admission stage, the higher the reversal rate would be for a court focused on case-by-case rescue. However, we should not expect the reversal rate to be $100 \%$. Real-life practice is not so idealized, and a court making an admission decision during a five-minute hearing can hardly be expected to make precise calculations about the likelihood a particular high court decision will be reversed. Nor do we expect a multi-member court to act with perfect unity of purpose.

A court that seeks to maximize error correction will focus on reviewing those judgments most likely to be reversed, regardless of the characteristics of those judgments that are observable to the empirical researcher. In other words, if its goal is to fix as many errors as possible, then regardless of whether a case is civil or criminal, involves individuals or the government, comes from Delhi or Mumbai, is litigated by a renowned senior advocate or an obscure junior lawyer, the Indian Supreme Court should admit the case subject to the criterion: Is the likelihood that we will eventually reverse this case high enough? This leads to the hypothesis that the likelihood of reversal that we in fact observe-the reversal rate among cases that the Court chooses to admit and hear on the merits-should be roughly similar across whatever categories of cases we examine-unless the Court is deviating from its goal of error correction because it is favoring certain groups of cases for access. This is a testable prediction. In Appendix B, we provide some evidence that, for many distinctions that do not implicate the underdog-versus-powerful distinction, we do not see systematic differences in reversal rates. This is consistent with our underlying premise, based on the qualitative evidence presented in Part III, that the Court is largely focused on individualized justice with an emphasis on identifying legal errors and maximizing reversal rates.

For a court that admits a significant number of cases involving error-correction, a low reversal rate for a subset of cases is a sign that the court is setting a low bar for admitting cases in that category. We use the term favored for access to refer to a group for which the Indian Supreme Court has set a lower bar (in terms of likelihood of reversal) for access. We say that the Court favors for access Group A over Group $\mathrm{B}$ if the Court makes it easier for petitioners from Group A to gain 
admission to the court. Cases brought by members of Group A are held to a lower threshold of likely error than cases brought by members of Group B. In other words, if Group A is favored for access, then the Court is willing to admit a relatively weak case from a member of Group A but will only admit a strong case from a member of Group B.

Because the Court holds petitioners from Group B to a higher standard for potential error, admitted cases in Group B are more likely to be reversed on the merits. Thus, even though (and precisely because) the Court is favoring litigants from Group A for admission, the Court eventually finds errors on the merits in a smaller fraction cases brought by litigants from Group A than cases brought by litigants from Group B.

To give a concrete example: we hypothesize that the Court is sympathetic to criminal defendants. If so, then the Court will be willing to admit SLPs brought by criminal defendants, even if their arguments do not appear very strong. The pool of appeals by criminal defendants will therefore contain a mix of strong and weak cases. This means that the Court will liberally grant criminal defendants access to a hearing on the merits, but, on average, such appeals will do relatively poorly. In short, the Court is willing to give theses particular underdogs their day in court, even if their cases are weak.

In contrast, we hypothesize that the Court will not be willing to admit weak SLPs brought by government prosecutors; the Court will admit only the strongest appeals brought by prosecutors. As a consequence, the Court will admit relatively fewer appeals by prosecutors, but a larger fraction of these appeals will succeed. In short, the Court will be "picky" with SLPs by prosecutors.

\section{B. Applying the Hit-Rate Methodology}

To the extent that we are correct that the Court's primary agenda is case-by-case rescue, our empirical analysis based on this premise will allow us to detect whether the Court favors (or disfavors) categories of cases. Categories of cases that are favored for access will, on average, have lower rates of success on the merits, because the Court is setting a lower bar at the admissions stage.

By looking at data on the Court's judgments on the merits of cases, we can draw inferences about the Court's behavior with respect to the admission of cases. This analysis rests on two key assumptions. First, we assume that all case categories have comparable fractions of petitions raising egregious errors versus petitions raising less obvious er- 
rors (which the Court still wants to correct, if they spot them). ${ }^{81}$ Second, we assume that settlement is rare in the Supreme Court; once a case is admitted for hearing, it is very unlikely to settle. We are not able to determine from data published by the Indian Supreme Court what number of cases settle after they have been admitted. Anecdotally, however, experienced litigators before the Supreme Court have informed us that relatively few cases settle after admission. Further, we acknowledge that different judges may be guided by different goals and may also have differing abilities in error spotting. We also note that the judge who admits the case may be different than the one who decides it on the merits and so both these judges may have a different view of error, which will add some noise to the data.

In applying our methodology, we make three sets of findings. First, our results provide evidence that the Court does, in fact, give greater access to the "common person" in the three situations. First, in examining the outcomes of individuals in cases where they face the government, we find that the Indian Supreme Court's admissions decisions are consistent with prioritizing access for the individual versus the government: The Court admits weaker cases from criminal defendants than government prosecutors, and in civil cases, the Court admits weaker cases when the petitioner is an individual in a case against the government than when the petitioner is the government facing an individual. ${ }^{82}$

Second, the Court is more likely to admit a case that alleges a constitutional violation as opposed to a case where no constitutional violation is alleged. This is consistent with the fact that the Court engag-

${ }^{81}$ We make the following technical assumption: the relative numbers of, for example, cases from Delhi that are $80 \%$ likely to be reversed versus $60 \%$ likely to be reversed are similar to the relative numbers of such cases from Mumbai. Because we cannot independently observe the quality of cases the court admits, we cannot empirically verify this assumption. But we might expect that, although cases involving different litigants or different geographic origins may be very different across different courts of first instance, the set of cases that make it to the point of appeal to the Supreme Court are highly selected and must share a large number of similar traits: they involve parties that can afford the time and expense of continuing to litigate, stakes that justify continued litigation, an unwillingness to settle, and underlying legal merits that justify the above traits.

82 Of course, not all criminal defendants are individuals. In our data, however, $82.5 \%$ of defendants are individuals. Further, in the criminal context at least, we believe that the government prosecutor is the more powerful party, even against an institutional defendant. 
es in norm-elaboration, in addition to case-by-case rescue. Constitutional cases are also more likely to involve the rights of individuals rather than businesses. ${ }^{83}$

Third, we find evidence that the Court's commitment to case-bycase rescue goes beyond individualized error correction or prioritizing individuals for access. Our results suggest that case-by-case rescue also involves a reluctance to defer to the judgments of the lower court-even when every lower court to hear the case has decided in favor of the same party. We elaborate these findings below.

1. Prioritizing Access to Individuals and Criminal Defendants over the Government

As noted above, when a group is favored for access, we predict that it will actually have a lower success rate on merits when it appeals to the Supreme Court than the success rate on merits for groups not favored for access.

In criminal cases, when the prosecution appeals to the Court, the Court rules in its favor $58.7 \%$ of the time. When the accused is the appellant, the Court rules in his favor $50.8 \%$ of the time. This suggests that the Court has a lower bar for admissions when an appeal is made by a criminal defendant than by the prosecution. Our results appear in Table 4.84

In civil cases, the Court rules in favor of the petitioner at a dramatically higher rate when the petitioner is the government $(69.3 \%)$ than when the petitioner is an individual (53.0\%). Once again, "underdogs" (individuals facing the government) have a lower rate of prevailing on the merits in the Supreme Court. If our analytical approach is valid, then the lower win-rate of individuals when appealing cases against the government suggest that the Court favors them for access; because the Court is less selective in taking petitions from this group, their petitions, on average, present weaker cases for reversal than petitions from the government.

${ }^{83}$ In our data, $66.0 \%$ of cases with constitutional challenges have an individual as a party.

84 When a case involved more than one plaintiff or defendant, party status was coded based on the first-named party. 
TABle 4. REVERSAl RATES By APPELLANT PARTy StATUS

PANel A. CRIMinal CASES ${ }^{85}$

\begin{tabular}{crrrr}
\hline Appellant & Prosecution & N & Accused & N \\
\hline Reversal Rate & $58.7 \%$ & 341 & $50.8 \%$ & 1013 \\
\hline
\end{tabular}

PANel B. Civil CASES 86

\begin{tabular}{crrrr}
\hline Appellant & Government & $\mathrm{N}$ & Individual & $\mathrm{N}$ \\
\hline Reversal Rate & $69.3 \%$ & 381 & $53.0 \%$ & 513 \\
\hline
\end{tabular}

\section{Prioritizing Access for Constitutional Cases}

Next, we test whether the Court favors for access constitutional cases, a category of cases to which one might expect an apex court (in a system without a separate constitutional court) to be especially receptive. From the raw data, it is hard to know whether this is the case in India. As Table 2 shows, an exceedingly small slice-only about $4 \%$ - of the caseload of the Court involves cases regarding constitutional questions. ${ }^{87}$ These recent numbers stand in contrast to the older finding of Gadbois that $15.9 \%$ of cases the Court decided from 1950 to

85 We test whether the reported difference in reversal rates is statistically significant using a one-sided $t$-test of difference-in-means on unpaired data with unequal variances. The difference in reversal rates is highly significant $(p=0.006)$.

86 We test whether the reported difference in reversal rates is statistically significant using a one-sided $t$-test of difference-in-means on unpaired data with unequal variances. The difference in reversal rates is highly significant $(p=0.000)$.

87 See Table 2. 
1967 were fundamental rights cases, which are merely a subset of all constitutional cases. ${ }^{88}$

Still, given the enormous overall caseload of the Court, this small slice of the docket amounts to a substantial number of cases-274 judgments deciding constitutional questions over a five-year period. 89 Thus, raw numbers alone do not necessarily tell us whether the Court is more willing to admit cases raising constitutional challenges than cases raising other issues. Hence, we turn to our hit-rate framework to ask: relative to other cases, are constitutional cases favored for access by the Court?

Our results appear in Table 5. Our findings support the conclusion that the Court favors for access cases involving constitutional challenges. In cases involving constitutional challenges, the Court reverses about 13 percentage points less often than in other cases, indicating that the Court may set a lower threshold for admitting constitutional cases for hearing on merits. One potential explanation for why cases raising constitutional issues might be favored for access is that the Court places a premium on expounding upon or clarifying constitutional law, and thus is willing to take cases for the purpose of norm elaboration, even if there is no possibility of a need to reverse the lower-court judgment. Another explanation is consistent with the Court's role as a people's court. Constitutional cases are disproportionately likely to consist of challenges implicating the rights of individuals than cases that do not involve constitutional challenges.

\footnotetext{
88 George H. Gadbois, Jr., "The Supreme Court of India: A Preliminary Report of an Empirical Study," Journal of Constitutional and Parliamentary Studies, Vol. IV, No. 1, Jan - March 1970 at 44.

89 Of these, only 156 were appeals and petitions from high courts and thus within the scope of the dataset employed in this paper. See Table 2. The remaining cases were within the original jurisdiction of the Court or were appeals from tribunals. By comparison, the U.S Supreme Court issued only 391 total merits opinions-whether on constitutional or non-constitutional questions-in its 2010 through 2014 terms. Opinions, SUPREME COURT OF THE UNITED STATES, https://www.supremecourt.gov/opinions/opinions.aspx (last visited Aug. 30, 2016) (the number of opinions was attained by adding the number of opinions in each of the five terms according to the SCOTUS site).
} 
TABLE 5: Reversal RATE, By CONSTItUtional CHALLENGE AND BENCH SIZE 90

\begin{tabular}{lrrrr}
\hline \multicolumn{1}{c}{ Bench Size } & 2 & 3 & 5 & \multicolumn{1}{c}{ Total } \\
\hline $\begin{array}{l}\text { Constitutional } \\
\text { Challenge }\end{array}$ & $\begin{array}{r}44.3 \% \\
(\mathrm{~N}=131)\end{array}$ & $\begin{array}{r}35.7 \% \\
(\mathrm{~N}=14)\end{array}$ & $\begin{array}{r}63.6 \% \\
(\mathrm{~N}=11)\end{array}$ & $\begin{array}{r}4 \mathrm{~N}=15 \% \\
\end{array}$ \\
$\begin{array}{l}\text { No Constitutional } \\
\text { Challenge }\end{array}$ & $\begin{array}{r}57.5 \% \\
(\mathrm{~N}=3589)\end{array}$ & $\begin{array}{r}60.0 \% \\
(\mathrm{~N}=230)\end{array}$ & $\begin{array}{r}65.4 \% \\
(\mathrm{~N}=26)\end{array}$ & $\begin{array}{r}57.7 \% \\
(\mathrm{~N}=3845)\end{array}$ \\
\hline
\end{tabular}

3. Case-by-Case Rescue as More than Individualized Error Correction

Finally, in addition to our results on the Court's greater liberality of access to individuals, criminal defendants, and constitutional claims, we consider another aspect of a "case-by-case rescue" approach: a desire to examine each case anew, without deference for the judgments of the lower courts. Consider cases where the court of first instance and the appellate court or courts to review the case have all agreed with the result, and compare them to cases where different stages of the process have yielded different results for the parties. A Court seeking to focus only on norm-elaboration is more likely to reject for admission cases where lower courts have agreed on the same result, than cases where lower courts have disagreed. The former situation suggests that the question raised by the case is one easily answered under existing law, while the latter situation suggests that there may be uncertainty in the law requiring resolution. Likewise, a court focused on error correction is also more likely to deny admission to cases where lower courts have agreed on the result; the fact of agreement indicates that it is less likely that this is a case in which

90 We test whether the reported difference in reversal rates is statistically significant using a one-sided $t$-test of difference-in-means on unpaired data with unequal variances. Across all cases, the difference in reversal rates is highly significant ( $p=0.001)$. This is also true for two-judge benches $(p=0.002)$. The difference is statistically significant for three-judge benches $(p=0.048)$. There is no meaningful difference for five-judge benches $(p=0.462)$. 
one or the other lower courts committed reversible error. Thus, for the same reasons given above, the Court should roughly equalize reversal rates between cases with lower court agreement and lower court disagreement. If the Court is not taking lower court agreement into account, however, we predict the Court's reversal rates for cases with lower court agreement will be lower than for cases with lower court disagreement. Put another way, when the lower courts agree, it is more likely that the outcome in the lower courts is "correct," and the Supreme Court will agree once it has a chance to examine the case more closely. But if the Court ignores the fact that the lower courts agreed, the Court will admit cases with the expectation of reversing, only to discover, once it has a chance to examine the case more closely, that it agrees with the lower courts.

We see from Table 2 that in our data, the lower courts agreed in $64.5 \%$ of cases. This leads us to the question: is the Court reversing more often cases where there is lower court agreement or cases where there is lower court disagreement? In Table 6, we see that reversal rates in cases with lower court agreement are consistently lower than reversal rates in cases with lower court disagreement. This is inconsistent with both error correction and norm elaboration. Instead, this suggests that the Court either underestimates how informative lowercourt agreement is, or the Court simply is uninterested in how the lower courts have judged the cases.

TABLE 6: Reversal RATE, BY LOWER COURT AGREemenT ${ }^{91}$

\begin{tabular}{lrrr}
\hline $\begin{array}{c}\text { Outcomes in lower } \\
\text { courts/tribunals }\end{array}$ & Agreement & Disagreement & N \\
\hline $\begin{array}{l}\text { Criminal Appeals from } \\
\text { High Courts }\end{array}$ & $48.8 \%$ & $55.7 \%$ & 991 \\
\hline
\end{tabular}

${ }^{91}$ We test whether the reported difference in reversal rates is statistically significant using a one-sided $t$-test of difference-in-means on unpaired data with unequal variances. Across all cases, the difference in reversal rates is highly significant $(p=0.000)$. For criminal cases, the difference in reversal rates is statistically significant $(p=0.028)$. The difference is not statistically significant for civil appeals from courts $(p=0.164)$. The difference is highly statistically significant for civil appeals from tribunals $(p=0.002)$. 
Civil Appeals from

High Courts

$61.9 \%$

Civil Appeals from

Appellate Tribunals

$54.3 \%$

$68.4 \%$

424

Total

$53.0 \%$

$61.1 \%$

2,292

$* * *$

In the end, we find that the Court's behavior is mostly consistent with the vision of the Court as a people's court-a court that is especially willing to hear the claims of individuals and give them greater access as compared to the government. The Court appears to generally maximize reversals by admitting the strongest candidates for reversal, which shows up in the data as fairly uniform reversal rates across categories of cases. The Court also prioritizes constitutional cases for access over non-constitutional cases. This both supports the view that the Court is acting to fulfill its function as court that elaborates constitutional norms, but also suggest that it is prioritizing cases that involve challenges by individuals that involve their constitutional rights. However, the Court appears to set a lower bar for admitting petitions brought by individual civil plaintiffs and criminal defendants, as well as for petitions raising constitutional arguments. In deciding which cases to admit, however, the Court does not seem to defer to the lower courts when both the trial and intermediate appellate courts agreed on the outcome.

\section{CONCLUSION: IMPLICATIONS FOR POLICY}

Despite recent criticism of the Court suggesting the contrary, we argue that the Court is acting in ways that are consistent with the vision of the Supreme Court as a court where an individual can seek justice when he or she has not received justice at any other level of the judiciary. It prioritizes for access criminal defendants versus the government, individual civil petitioners versus the government, and cases alleging constitutional questions versus cases not alleging constitutional questions. In this way, the Court remains true to its institutional vision as a court of the people.

The Court's approach, however, raises challenges for its ability to perform its functions effectively given the rising number of cases that 
seek admission to the Court. Combined with the increase in petitions overall, the court's unwillingness to narrow its approach to exercising its discretionary jurisdiction puts the Court in a situation where the crush of cases leads to long delays and overworked justices.

Given finite judicial resource, the problem of overcrowding of the docket can be overcome in multiple ways. The Court could decide to shift focus to norm-elaboration, and limit itself to admitting cases that fit this criteria. If the Court wants to preserve its error-correction function, it could limit its caseload by placing greater emphasis on selecting only those cases with the highest likelihood of reversal. This may involve sacrificing the goal of providing greater access to individuals. The Court could also limit its caseload, but at the same time, preserve the case-by-case rescue approach, by simply deferring more significantly to lower court agreement. This would allow the Court to continue to favor individuals for access, while also denying admission to greater numbers of cases that it would have otherwise upheld anyway.

Ultimately, though, a case-by-case rescue strategy may no longer be sustainable with the increasing number of petitions before it. By focusing more on norm-elaboration, the Supreme Court would also put pressure on the need to increase the competence of and resources for lower courts. 


\section{APPENDIX A: Notes ON DATA CODING}

The hand-coding project entailed an analysis of cases decided by the Supreme Court from 2010 to 2015 (data from 2010 through 2014 have been fully analyzed and are presented in this paper). We have used the SCC reporter for coding. The SCC reporter was selected over Juris, the other major Supreme Court reporter in India, due to greater reporting of decisions by the former. Each year has about 15 volumes on an average.

Some cases from a particular year are reported in SCC volumes of subsequent years. For instance, a case that was decided in 2010 may be reported in an SCC volumes from 2015. Thus, our dataset used in this paper is exhaustive to the extent that all cases that were decided between 2010 and 2014, and form a part of the 2010-2015 SCC volumes, have been coded. However, cases decided in our study period that were reported in the 2016 SCC volumes and thereafter do not form a part of the dataset. Also, cases that were decided prior to 2010 but were reported in the 2010-2015 SCC volumes have been excluded.

Below, we list the variables that our research assistants handcoded and provide notes on selected variables.

\section{- Internal Case ID}

The cases have been given a unique Case ID in the "year of decision_month of decision_serial number" format. There are broadly three sorts of cases: a) where there is one petitioner and one respondent; b) where there are multiple petitioners and/or respondents (the case title will read X \& Y v. Z or X and Anr. v. Z; or X and Ors. v. Z); and c) where multiple petitions have been tagged together (case title will read $\mathrm{X}$ v. $\mathrm{Y}$ and $\mathrm{Z}$ v. A.). In case of (b), there is a single row entry. In the case of (c), the individual petitions (i.e. X v. Y, and Z v. A) have been disaggregated into separate rows for the purpose of coding, however, the same internal case ID has been assigned to them.

\section{- $\quad$ Case Type}

We have coded the cases along the following categories in accordance with what was provided in SCC.

WP (C): Writ Petition (Civil)

WP (Cr): Writ Petition (Criminal)

CA: Civil Appeal 
Cr.A: Criminal Appeal

SLP (C): Special Leave Petition (Civil)

SLP (Cr): Special Leave Petition (Criminal)

OS: Original Suit

TP (C): Transfer Petition (Civil)

TP (Cr): Transfer Petition (Criminal)

Conmt. P (C): Contempt Petition (Civil)

Conmt. P (Cr): Contempt Petition (Criminal)

CA/SLP: Civil Appeal arising out of SLP

Cr.A/SLP: Criminal Appeal arising out of SLP

Special Reference

Curative (C): Curative Petition (Civil)

Curative (Cr.): Curative Petition (Criminal)

Review (C): Review Petition (Civil)

Review (Cr.): Review Petition (Criminal)

Election Petition

Reference U/A 317

Arb.P.: Arbitration Petition

Crl.MP.: Criminal Miscellaneous Petition

- Case Number

We have coded all the case numbers in the "case number/year" format, and separated by a semi-colon.

- Indian Supreme Court Year of Filing 
If the case has multiple case numbers, the oldest year of filing from such case numbers has been coded as the Indian Supreme Court Year of Filing. For instance: for case numbers 1/2000, 2/2004, 3/2006; the relevant entry is 2000 .

- Year of Supreme Court decision

The year in which the Supreme Court case was decided has been coded.

- Month of Supreme Court decision

The month in which the Supreme Court case was decided has been coded.

- Day of Supreme Court decision

The day on which the Supreme Court case was decided has been coded.

- Reportable

All cases that form a part of the dataset are reportable.

- Judgment or Order

The SCC volumes typically consist of judgments (coded as ' $\mathrm{j}$ ') and orders (coded as 'o'). We have also included cited orders and records of proceedings.

- $\quad$ Single or Multiple Petitioners

Case titles that read "X \& Y v. Z", or "A \& Anr. v. B", or "C \& Ors. v. D" have multiple petitioners. Case titles that have a single petitioner have been coded as 's', and cases with multiple petitioners have been coded as ' $m$ '. The term 'petitioner' is being used generally to connote the person who has approached the Supreme Court in the instant case. Thus, irrespective of the nature of the case, the person approaching the Supreme Court is being referred to as the petitioner.

- Single or Multiple Respondents

Case titles that read "X v. Y v\& Z", or "A v. B \& Anr.", or "C v. D \& Ors." have multiple respondents. Thus, case titles that have a single 
respondent have been coded as 's', and cases with multiple respondents have been coded as ' $m$ '. The term 'respondent' is being used generally to connote the person against whom the petitioner has approached the Supreme Court in the instant case.

- First Named Appellant

The person who has approached the Supreme Court is being referred to as the 'appellant' herein. Thus, even if the case is an Original Suit or a Transfer Petition or a writ under Article 32, and so on, i.e. irrespective of the nature of the case, such person is being referred to as the appellant. (Thus, "appellant" is equivalent to "petitioner" as used in the previous variable definitions.) In case of multiple appellants, the first named appellant is coded. For example: in $\mathrm{X}, \mathrm{Y} \& \mathrm{Z}$ v. $\mathrm{B}$, the first named appellant is $\mathrm{X}$.

- $\quad$ First Named Respondent

The person against whom the appellant has approached the Supreme Court in the instant case is referred to as the 'respondent' herein. In case of multiple respondents, the first named respondent is coded. For example: in $\mathrm{X}$ v. Y, Z \& B, the first named respondent is $\mathrm{Y}$.

- Appellant Country

The country of origin/residence is coded as the appellant country.

- Respondent Country

The country of origin/residence is coded as the respondent country.

- Appellant legal status in Supreme Court

The categories along which the legal status is coded are: Indv. (Individual), Inst. (Institution) and Govt. (Government). Government companies and institutions come under the ambit of 'Govt'. When the party is a judicial institution (for example: the High Court of Delhi), the same is coded as 'Govt.'. Institutions represented by persons (for instance, Secy. General, XYZ Institution) are coded as 'Inst.'

- Respondent legal status in Supreme Court

The categories along which the legal status is coded are: Indv. (Individual), Inst. (Institution) and Govt. (Government). Government 
companies and institutions come under the ambit of 'Govt'. When the party is a judicial institution (for example: the High Court of Delhi), the same is coded as 'Govt.'. Institutions represented by persons (for instance Secy. General, XYZ Institution) is coded as 'Inst.'

- If the appellant is individual, gender

The categories along which the gender is coded are: $\mathrm{f}$ (female), $\mathrm{m}$ (male), o (other), not clear and n/a. When the gender of the individual is not decipherable from the case, 'not clear' has been used. Institutions and government entities have been coded as ' $\mathrm{n} / \mathrm{a}$ '.

- If the respondent is individual, gender

The categories along which the gender is coded are: $\mathrm{f}$ (female), $\mathrm{m}$ (male), o (other), not clear and n/a. When the gender of the individual is not decipherable from the case, 'not clear' has been used. Institutions and government entities have been coded as 'n/a'.

- Name(s) of original plaintiffs / petitioner (separate by semicolons) or of prosecuting entity in criminal cases

This refers to the name of the person who first initiated the issue in question in the court of first instance. Usually, the State as the prosecuting entity is coded in this section. However, it is imperative to look at the issue in each case. For example: in a criminal case against the accused, X, where the issue before the Supreme Court is the grant of bail to $\mathrm{X}$-although the case was originally initiated by the State, but the case qua the issue in question (i.e. bail) was initiated by the accused, X would be coded herein.

- Name(s) of defendants/respondents

This refers to the name of the person against whom the issue in question was first initiated in the court of first instance. Usually, the accused in a criminal case is coded in this section. However, it is imperative to look at the issue in each case. For example: in a criminal case against the accused, $\mathrm{X}$, where the issue before the Supreme Court is the grant of bail to $\mathrm{X}$-although the case was originally initiated by the State, but the case qua the issue in question (i.e. bail) was initiated by the accused, State would be coded herein.

- Case originated in Tribunal or Regular Court 
This refers to the initiation of the case with respect to the issue in question before the Supreme Court. Consumer Courts, Reference Courts (under the Land Acquisition Act), Labour Courts, CESTAT, and other such institutions have been coded as Tribunal. Administrative authorities have not been included in the dataset.

- Date of institution of case in court of first instance/date of chargesheet [e.g. 30.10.08 or 10.08 or 08]

The Court of first instance refers to the first dispute resolution institution to which the case was taken. For example, in a tax matter, the first institution would be the tax tribunal (and not the Assessing Officer). So also, for any administrative matter, the court of first instance will be the court/tribunal to which the decision of the administrative officer was appealed. In some cases an appeal may first lie within the administrative office itself (for example under RTI, the first appeal from the decision of the PIO lies with the Appellate Officer within that institution). We do not consider the PIO or the Appellate Officer as the court of first instance. The Information Commission is the Court of first instance.

- Name of court of first instance (if different from court appealed from) [Designation, Location, State]

The court where the case was first initiated with respect to the issue in question has been identified and coded here. If the case was directly appealed to the court from which the case went to the Supreme Court (e.g, case from first instance went to a High Court and then went to the Supreme Court), we have filled in n/a here-such court has been coded under the parameter 'Court appealed from to Indian Supreme Court'.

- Outcome in court of initial appeal (if more than one appeal)

This parameter has been coded along the categories: Pl./Pet., Def./Resp., Part Allowed. Thus, it has been mentioned whether outcome the outcome in the court of initial appeal was in favor of the original pl./pet or original respondent, or was part allowed [not the designation of parties in the case before the Supreme Court].

- Date of disposition in court of initial appeal (if more than one appeal) [e.g. 27.3.11] 
- Court of second appeal (if different from court appealed from) [Bench, Court]

If the case went through three courts before it came up before the Supreme Court, then the second court has been coded herein. In cases where the court of second appeal was the same as the court appealed from, we have entered n/a.

- Outcome in court of second appeal (if different from court appealed from)

This parameter has been coded along the categories: Pl./Pet., Def./Resp., Part Allowed. Thus, it has been mentioned whether the outcome in the court of second appeal was in favor of the original pl./pet or original respondent, or was part allowed [not the designation of parties in the case before the Supreme Court].

- Date of disposition in court of second appeal (if different from court appealed from) [e.g. 27.3.11]

- Court appealed from to India supreme court [Designation/Bench, Court]

- Outcome in court appealed from in favor of

This parameter has been coded along the categories: Pl./Pet., Def./Resp., Part Allowed. Thus, it has been mentioned whether outcome in the court appealed from was in favor of the original pl./pet or original respondent, or was part allowed [not the designation of parties in the case before the Supreme Court].

- Date of decision of court appealed from [e.g., 29.8.2012]

- Was this case referred to current bench from a smaller bench of the Supreme Court

In cases where an important question of law is involved or where the judges have previously disagreed with each other in forming an opinion, the case is referred to a larger bench of the Supreme Court. If the case in question is a case that has been referred by a smaller bench, the parameter has been coded as ' $y$ ' (yes). Otherwise, the parameter is coded as 'n' (no).

- Party appealing to Supreme Court 
This parameter has been coded along the categories: Pl./Pet., Def./Resp. The Pl./Pet. and Def./Resp refer to original Pl./Pet. and original Def./ Resp. as per the case in court of first instance.

- Bench Size in Supreme Court

- Outcome in Indian Supreme Court

This parameter has been coded along the following categories:

Appeal Allowed

Appeal Dismissed

Pet. Allowed

Pet. Dismissed

App. Part Allowed

Pet. Part Allowed

Referred to larger bench

In cases in which the Court made no decision (for instance, in record of proceedings), we have filled in 'n/a'.

- $\quad$ Subject Matter

Since the subject matter assigned to a case by the Supreme Court registry is unavailable, the subject matter has been assigned by the coders themselves, based on the issue in question. The subject matter has been filled using the following categories provided by the Supreme Court handbook:

Labour Matters

Rent Act Matters

Direct Taxes Matters

Indirect Taxes Matters

Land Acquisition \& Requisition Matters 
Service Matters

Academic Matters

Letter Petition \& PIL Matters

Election Matters

Company Law, MRTP \& Allied Matters

Arbitration Matters

Compensation Matters

Habeas Corpus Matters

Criminal Matters

Appeal Against Orders of Statutory Bodies

Family Law Matters

Contempt of Court Matters

Ordinary Civil Matters

Appointments Etc. Of Constitutional Functionaries

Statutory Appointments

Personal Law Matters

Religious \& Charitable Endowments

Mercantile Laws, Commercial Transactions Including Banking

Simple Money \& Mortgage Matters Etc.

Matters Relating To Judiciary

Admission To Educational Institutions Other Than Medical \& Engineering

Establishment And Recognition Of Educational Institutions 
Eviction Under The Public Premises (Eviction) Act

Mines, Minerals And Mining Leases

Land Laws And Agricultural Tenancies

Admiralty And Maritime Laws

Matters Relating To Commissions Of Enquiry

Matters Relating To Consumer Protection

Matters Pertaining To Armed Forces \& Para Military Forces

Admission/Transfer To Engineering And Medical Colleges

Allocation Of 15\% All India Quota In Admission/ Transfer To Medical Colleges

Matters Relating To Leases, Govt. Contracts \& Contracts By Local Bodies

State Excise-Trading In Liquor-Privileges, LicencesDistilleries Breweries

Reference Under Article 143 Of The Constitution Of India

Reference Under Article 317(1) Of The Constitution Of India

Reference Under Section 11 Of The Competition Act, 2002

Reference Under Right to Information Act, 2005

Some other categories that do not form a part of the SC handbook, i.e., Constitutional Matters and Environmental Matters, have been added.

- Issue

A one line description of the issue involved.

- Is this a PIL

This has been coded using the following categories: Y (Yes), N (No), and Not Clear 
- Is this an Interlocutory Application in an ongoing matter?

We have coded interlocutory application in accordance with the information provided by the SCC headnote and the text of the decision.

- Was the constitutionality of State action challenged in this case?

The challenge to the constitutionality of State action has been further divided into the following categories:

Yes-Legislation for violation of fundamental rights

Yes-Legislation for being ultra vires other parts of the constitution

Yes-Const. Amndmt/Legislation for violation of Basic Structure)

Yes-Executive Action for violation of fundamental rights

Yes-Executive Action for violation of other parts of the constitution

Yes-Executive Action for violation of basic structure

- If constitutionality of state action was challenged, did the Supreme Court strike down or uphold the state action

The response of the Supreme Court to the challenge has been coded in this parameter along the following categories: Struck down, Upheld, Altered.

- Party ordered to pay costs by Supreme Court

The party that has been ordered to pay costs of the proceedings to the other party has been coded as Pl./Pet. (original plaintiff), and Def./Resp. (original defendant), 'Not Stated' and 'Bear Own Costs.'

- Supreme Court Opinion Author

If the opinion author is not provided in a case, for instance in an order, we have coded the names of all judges in the category of 'Joined By'. 
- Joined By (separated by semi-colon)

This refers to a concurring judge who does not write a separate opinion.

- Concurring Judgment Author

This refers to the author of a separate concurring opinion.

- Joined by (separated by semi-colon)

This refers to the judge who concurs with the opinion of the author of the concurring judgment.

- Second Concurring judgment author

- Joined by (separated by semi-colon)

- $\quad$ Third Concurring Opinion (author, joined by separated by semi colon)

- Fourth Concurring Opinion (author, joined by, separated by semi colon)

- Dissenting opinion author (including Part Concurring/Part Dissenting)

This includes part concurring and part dissenting judgments as well.

- Overruling

If the decision overrules any previous Supreme Court decision, the same is coded as ' $\mathrm{Y}$ ' (Yes). No such overruling has been coded as ' $N$ '. Overruling of High Court decisions or reversal of other decisions does not constitute overruling for our purposes. We have relied on the SCC headnote to code this parameter.

- Counsel for Pl./Pet.

This refers to the counsel for the original plaintiff or the original petitioner and not the appellant of the case before the SC. We have relied on the SCC headnote for this purpose. In case the SCC headnote does not mention the status of the counsels or is ambiguous in this re- 
gard, the researchers have gone through the case and coded it. The parameter has been coded along the following categories: Party in person, Senior Advocate, Advocate and Legal Aid

In case the counsels are unclear, we have filled it in as n/a. In case of multiple counsels, for instance, in a case where both senior advocate and advocate have been mentioned, we have coded it as senior advocate only.

- Counsel for def./resp.

This refers to the counsel for the original defendant or the original respondent. The researchers have relied on the SCC Headnotes for this purpose. In case the SCC headnote does not mention the status of the counsels or is ambiguous in this regard, the researchers have gone through the case and coded it. The parameter has been coded along the following categories: Party in person, Senior Advocate, Advocate and Legal Aid.

In case the counsels are unclear, we have filled it in as n/a. In case of multiple counsels, for instance, in a case where both senior advocate and advocate have been mentioned, we have coded it as senior advocate only.

- Whether Court appointed Amicus?

In case the Court has appointed an amicus curiae, we have coded it as ' $\mathrm{Y}$ '. If there is no amicus, we have written ' $\mathrm{N}$ '.

- No. of pages in opinion

The number of pages does not include the headnote given in the SCC volumes.

- Name of coder

- Remarks

\section{APPEndix B: CONSISTENT REVERSAL RATES ACROSS MAJOR CATEGO- RIES OF CASES}

In the main text, we focused on comparing reversal rates across categories of cases and litigants where we expected the Court to deviate from its overall tendency toward individualized error correction in order to favor certain litigants or types of cases for greater access to the Court. These favored groups included individuals facing the gov- 
ernment. We interpreted this as reflecting a commitment to case-bybase rescue-looking out for the underdog in "David versus Goliath" battles. These favored groups also included cases involving constitutional challenges. We interpreted this as reflecting the norm elaboration aspect of the Court as well as favoring cases that involve individual rights.

We demonstrate here that for several other categories of cases, however, we did not have strong priors about which cases would or would not be favored by the Court, and if our assumptions about the Court's emphasis on individualized review are correct, we would predict that, when the Court does not favor particular categories of cases for access, we should see roughly similar reversal rates across categories. This would be consistent with a court that simply admits the high-likelihood-of-reversal petitions and denies the rest. We present three such comparisons below, which indicate that the deviations we found for individual-versus-government litigation are not typical of other differences across categories, lending some further credence to our interpretation that they reflect greater access to individuals. 
TABle A1. Reversal RAtes By SubJeCt MATTER CATEGory92

\begin{tabular}{lrr}
\hline \multicolumn{1}{c}{ Subject Matter Category } & Reversal Rate & $\mathrm{N}$ \\
\hline $\begin{array}{l}\text { Mercantile Laws, Commercial } \\
\text { Transactions }\end{array}$ & $50.0 \%$ & 68 \\
Appeal Against Orders of Statutory & $52.6 \%$ & 57 \\
Bodies & $52.9 \%$ & 1302 \\
Criminal Matters & $53.1 \%$ & 81 \\
Land Laws and Agricultural Tenancies & $53.2 \%$ & 139 \\
Direct Taxes Matters & $53.3 \%$ & 154 \\
Indirect Taxes Matter & $56.0 \%$ & 50 \\
Matters Relating to Consumer Protection & $57.2 \%$ & 4002 \\
\hline All Subject Matter Categories & $60.2 \%$ & 399 \\
\hline Ordinary Civil Matter & $60.3 \%$ & 529 \\
Service Matters & $61.9 \%$ & 84 \\
Family Law Matters & $62.7 \%$ & 75 \\
Labour Matters & $64.1 \%$ & 64 \\
Rent Act Matters & $64.2 \%$ & 260 \\
Land Acquisition \& Requisition Matters & $64.8 \%$ & 54 \\
Matters Relating to Judiciary & $66.7 \%$ & 93 \\
Arbitration Matters & $81.3 \%$ & 123 \\
Compensation Matters & & \\
\hline
\end{tabular}

First, we compare reversal rates across subject matter categories. In Table A1, we report the reversal rates among cases in each of the Court's subject matter categories for which there were at least 50 judgments and thus a reasonable size sample of cases is available. We omit, however, cases designated "constitutional cases," as we believe

92 See Appendix A, for a complete list of the subject matter categories addressed by the Supreme Court. 
the Court treats these cases differently-a claim that we tested above in Part IV.B.2. It is apparent from Table A1 that the reversal rates across categories are fairly symmetrically bunched around the overall average of 57 percent, which is exactly what we would expect to see of a court whose goal was to select cases based on probability of error. Of course, the equalization is only approximate, and some variation across categories is inevitable due to random variation. For example, there is a single, outlier category - compensation matters-with an unusually high reversal rate. (This is consistent with random variation across categories, although it could be due to the Court treating compensation matters differently from other cases. Because we did not form an a priori hypothesis-i.e., before looking at the data-about this subject matter category, we do not analyze it separately.) These findings suggest that the Court roughly equalizes reversal rates across categories of cases and bolsters the argument that when there are deviations in reversal rates between categories of people those suggest something about the admissions process.

Second, another test of the hit-rate methodology is whether the Court is equally likely to reverse cases arising from tribunals rather than courts. Just as we did above, we could ask whether the origin of a case is correlated with its likelihood of being reversed. Here, too, we find the Supreme Court acting consistent with error correction. Among civil cases (tribunals handle virtually no criminal cases), the Court reverses $61.5 \%$ of appeals from tribunals and $58.5 \%$ of appeals from courts - a small difference, and in fact the two reversal rates are statistically indistinguishable from each other. ${ }^{93}$ These findings further support the view that where we do find deviations in win rates across categories that we had predicted a priori would be favored, those reflect preferences of the Court rather than being randomly occurring.

Third, we examine differences in reversal rates based on the high court from which the case came. India's judicial system has 24 regional appellate courts, called high courts, whose geographical jurisdictions correspond to Indian States (although some high courts encompass more than one Indian State). This test is particularly valuable, because there are systematic differences across regions of India that are likely to drive systematic differences in the strength of petitions

${ }^{93}$ We test whether the difference in reversal rates is statistically significant using a t-test of difference-in-means on unpaired data with unequal variances. The difference in reversal rates is not even close to statistical significance $(p=0.191)$. 
from high courts. We would expect that regions of India that are farther from Delhi or that have lower per capita GDP generate relatively fewer appeals that reach the Supreme Court. ${ }^{94}$ Because such cases face higher costs of reaching the Court (either because of sheer distance or poor local infrastructure), we expect only the strongest appeals from such states would reach the Court (i.e., it would not be worth the relatively high cost to bring a weak petition to Delhi for review). Conversely, if it is relatively easier to bring a case to the Court from a high court in a wealthier and more proximate region, then we should see not only more such cases brought to the Court, but also a larger share of relatively weak petitions for review.

This provides a partial test of our hit-rate methodology. If our premise that the Court seeks to maximize error correction is accurate, then the Court will not simply admit cases in proportion to the numbers arriving from each high court. Rather, it will focus on admitting only those that appear most likely to be reversed, regardless of their high court of origin. If so, distance to the Court and state per capita GDP might predict the number of cases that the Court hears but should not predict the reversal rate among cases from each high court.

Graphical evidence supports these predictions. ${ }^{95}$ Figure A1 shows a scatter plot (with trend line) in which each dot represents one of the 20 high courts for which we have GDP data for its component States and from which the Supreme Court decided cases during the sample period. ${ }^{96}$ The horizontal axis is GDP, while the vertical axis is the number of cases. As we would expect, economic conditions in the home states of the high courts are a strong predictor of cases reaching, and being admitted, by the Supreme Court. Importantly, this suggests not only that these high courts are sending different numbers of cases to

94 See generally Theodore Eisenberg, Nick Robinson, and Sital Kalantry, Litigation as a Measure of Well-Being, 62 DEPAUL L. REV. 247 (establishing empirical relationships between litigation activity in region and economic indicators); Nick Robinson, A Quantitative Analysis of the Indian Supreme Court's Workload, 10 J. EMPIRICAL LEGAL STUD. 570 (2013) (documenting correlations between distance to Delhi and petitions filed in the Court).

${ }^{95}$ Regression analysis (unreported but available from authors) yields equivalent conclusions.

96 We have GDP data for a twenty-first high court, the High Court of Meghalaya, which split in 2013 from the High Court of Gauhati. We combine it with the High Court of Gauhati in these regressions. For high courts whose jurisdiction covers more than one Indian state, we use the population-weighted average state-level GDP in assigning GDP to high courts. 
the Supreme Court, but different mixes of cases that differ along dimensions, such as likelihood of reversal, that are unobservable to us. ${ }^{97}$

Figure A2 is identical to Figure A1 except that the vertical axis plots the reversal rate in the Supreme Court. Despite the fact that per capita GDP predicts very different numbers and types of cases being decided by the Court, we see no correlation between per capita GDP and the reversal rate in the Supreme Court. ${ }^{98}$

Figures A3 and A4 repeat this exercise for distance to Delhi. (We measure distance from each high court courthouse to the Supreme Court in Delhi). Again, while we do see the expected negative correlation between distance and the number of cases decided by the Court, there is essentially no correlation between distance and reversal rate..$^{99}$

Taken together, these results suggest that the Court is not prioritizing any one High Court for admission, but is instead admitting only those cases most likely to be reversed, regardless of origin. ${ }^{100}$

${ }^{97}$ Note that the differences in case numbers cannot be explained by population differences across high courts. In our data, per capita GDP and population are negatively correlated, which strengthens the inference that cases coming from high per capita GDP regions are different in nature than those from lower per capita GDP regions. We should note that we have determined the number of cases coming from these high courts based on the number of reported decisions of the Supreme Court dealing with such matters. We do not currently have independent data on the number of cases being filed for admission from each high court.

98 To statistically test our claim that there is no relationship between per capita GDP and reversal rate, we run a bivariate regressions of reversal rate on per capita GDP. The coefficient on per capita GDP is extraordinarily small and not statistically significant $(\beta=-0.000, p=0.947)$. (For comparison, we run a bivariate regression of number of cases on per capita GDP. Consistent with the graphical evidence, the coefficient on per capita GDP is large and highly statistically significant $(\beta=0.116, p=0.007)$. We note, too, that analysis based on total GDP, rather than per-capita GDP, is nearly identical.

99 To statistically test our claim that there is no relationship between distance and reversal rate, we run a bivariate regressions of reversal rate on distance. The coefficient on distance is not statistically significant $(\beta=-0.018$, $p=0.524$ ). (For comparison, we run a bivariate regression of number of cases on distance. Consistent with the graphical evidence, the coefficient of distance is large, but it is not statistically significant $(\beta=-34.47, p=0.430)$.

100 This finding supports, but of course does not prove, our hypothesis. For example, these results are consistent with the (implausible) hypothesis that the Court admits cases randomly and also decides cases randomly by reversing $57 \%$ of the time, regardless of the facts of the case. 
Figure A1. Total Cases and Per Capita GDP, By High Court

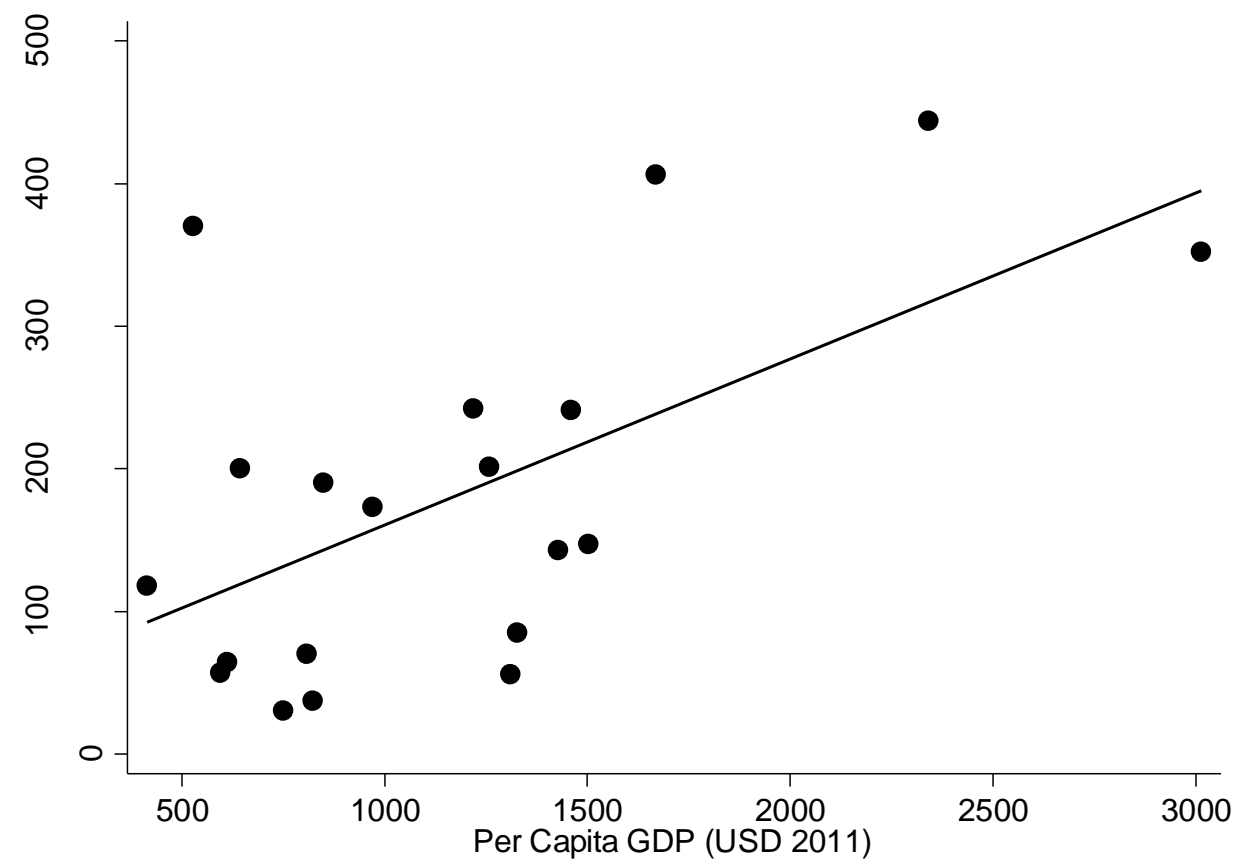


Figure A2. Reversal Rate AND Per CAPita GDP, By High CourT

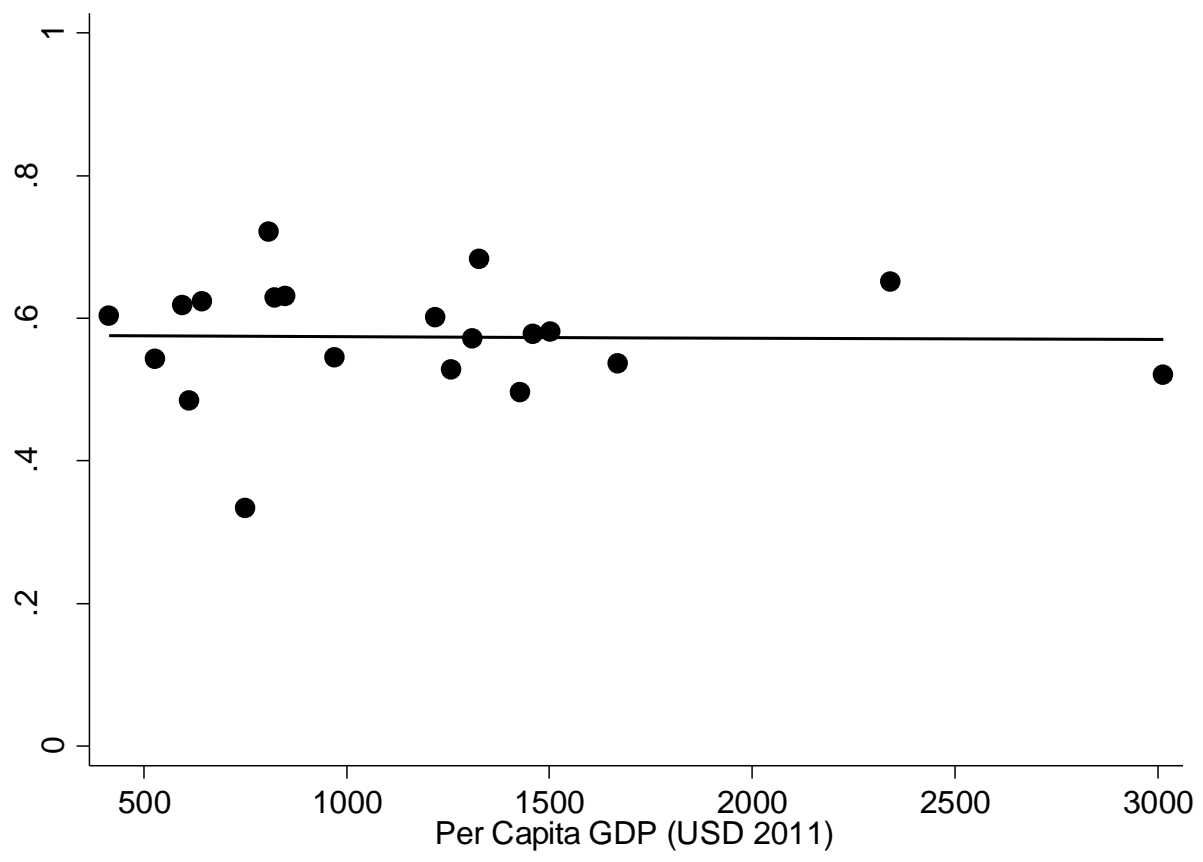


Figure A3. Total Cases and Distance to Delhi, By High CourT

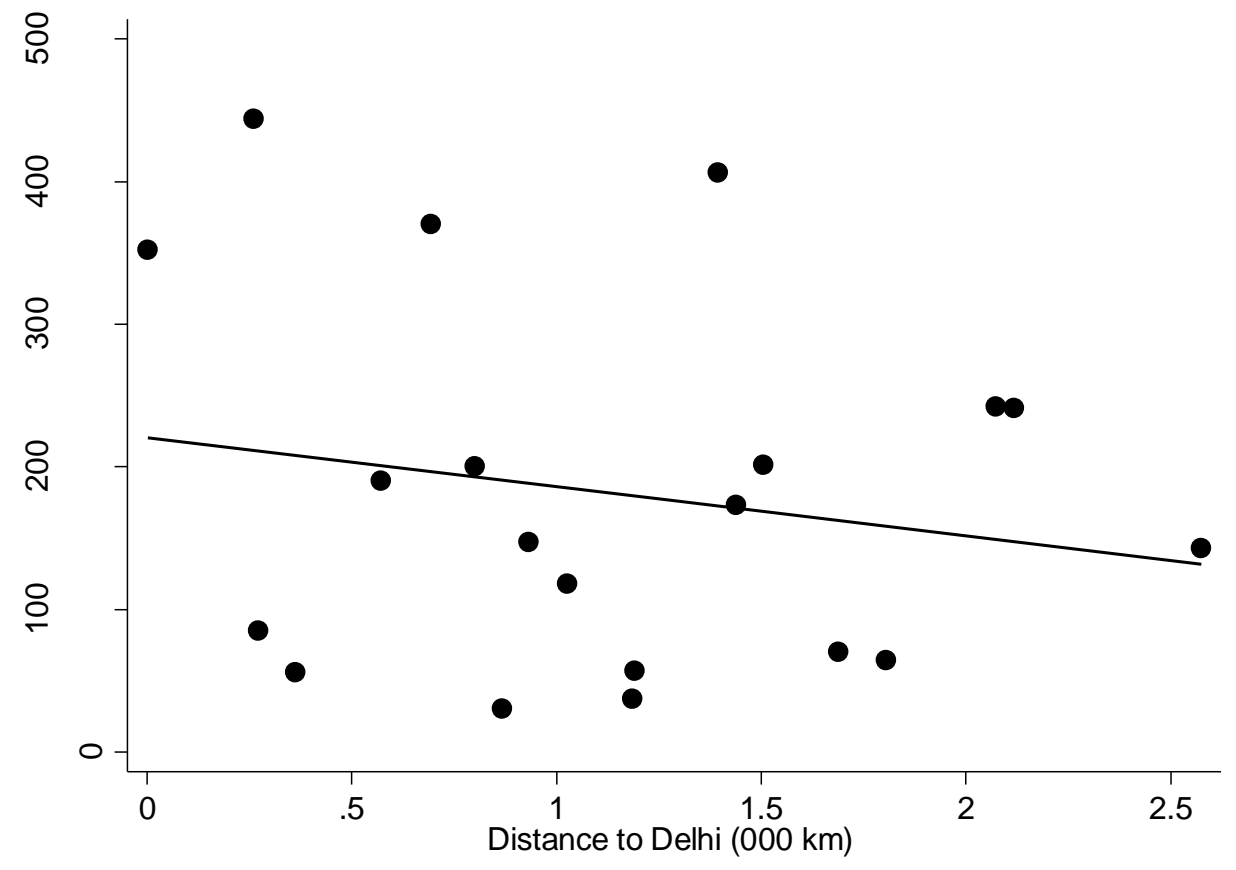


Figure A4. Reversal Rate AND Distance to Delhi, By High CoURT

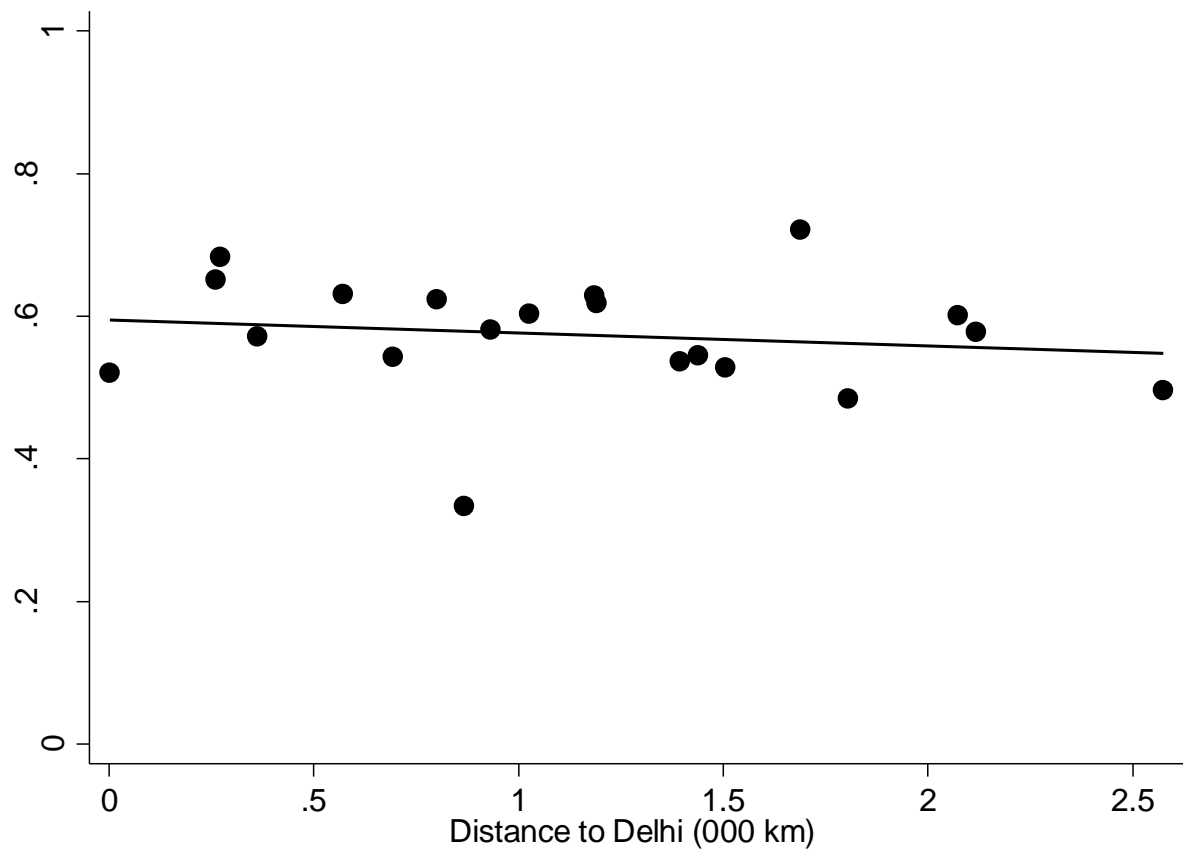

